ارزيابى لاينهاى حاصل از تلاقى بين گونهاى در دو زمينه زنتيكى متفاوت در جو تحت رزيمهاى مختلف آبى

مهسا ذى كنى'، محمدمهدى مجيدى ‘"، محمد براتى"، اميرحسين اوسيوند و دانيال سرفراز

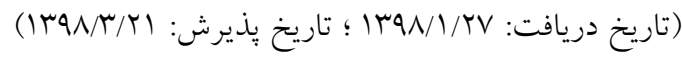

حكيده

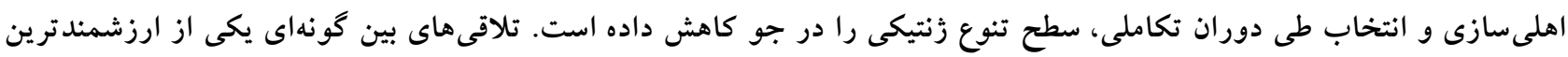

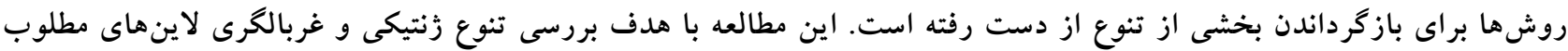

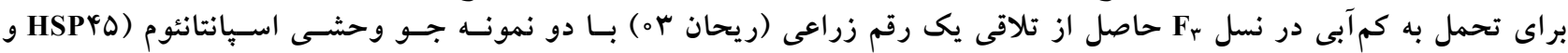

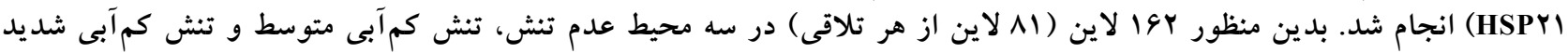

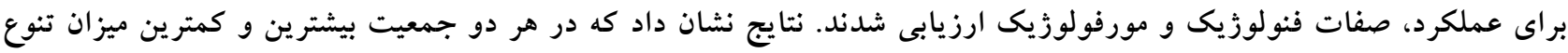

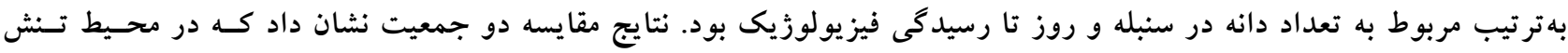

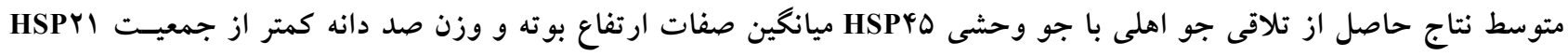

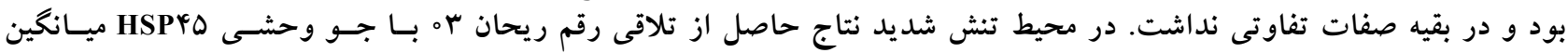

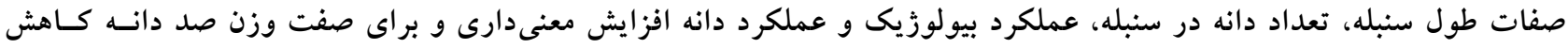

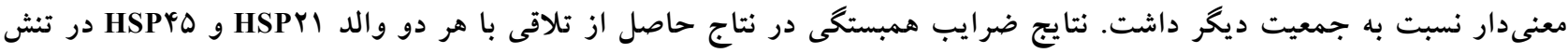

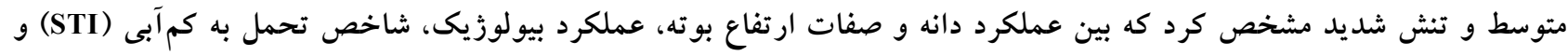

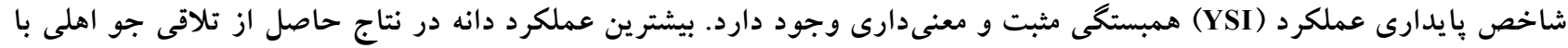

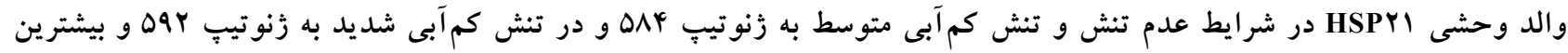

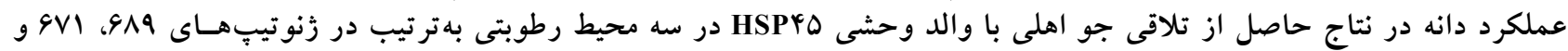

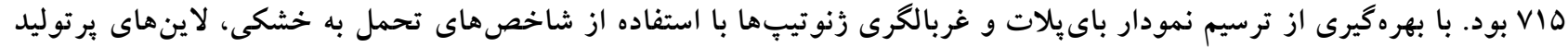

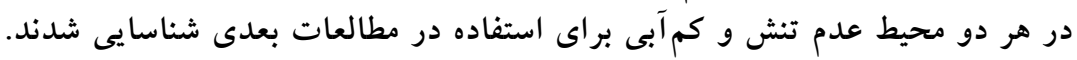

$$
\text { وازمهاى كليدى: تنش كم آبى، غربالكرى، آخمنت، تنوع زنتيكى، جو وحشى اسپانتانئوم }
$$

l، r، r و أ. بهترتيب دانشجوى سابق كارشناسى ارشد، استاد، دانشجوى سابق دكترى و دانشجويان سـابق كارشناسى، گروه زراعت و اصلاح نباتات، دانشكده كشاورزى، دانشخاه صنغتى اصفهان majidi@iut.ac.ir : مسئول مكاتبات: يست الكترونيكى 
رشته كوههاى زاكرس بر اكنــه اسـت و احتمـال مسىرود داراى

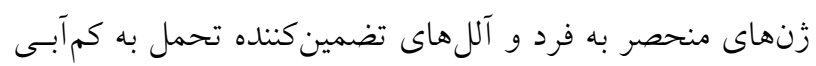

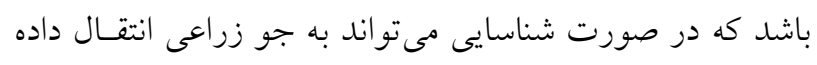

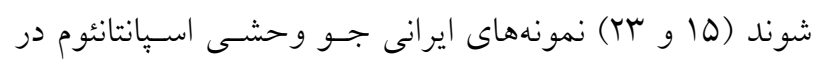

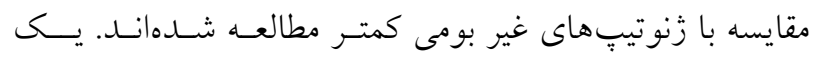

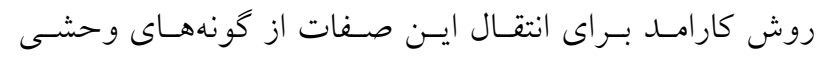

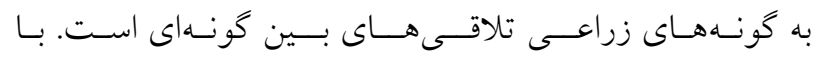

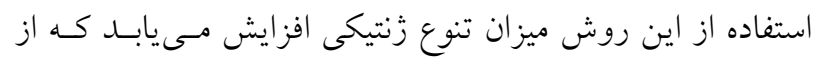

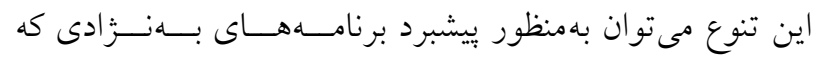
از طريق صفات مورفولوزيكى، ميسر مىشود اســـفاده كـــــد.

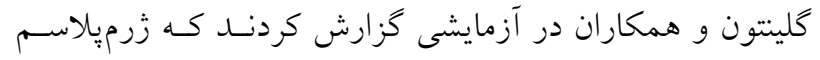
جو وحشى بهعنوان منبعى غنى از زنهاى جديـــ اسـت كـه بـاــا

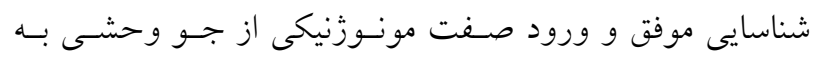

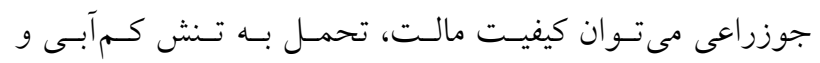
بايدارى را در جو زراعى افـزيش داد (9). هادجيكريستودولوا

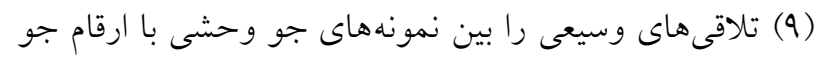

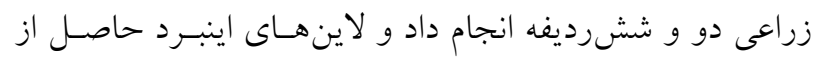

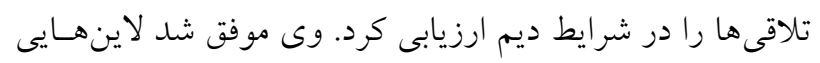

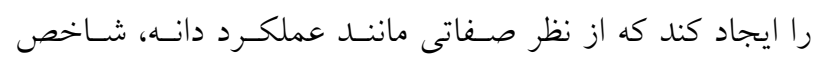

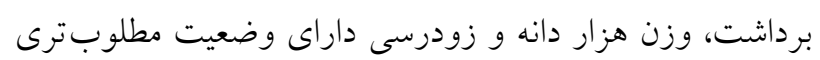

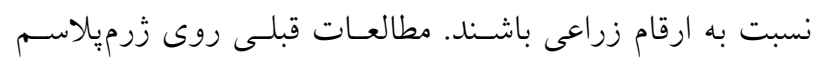

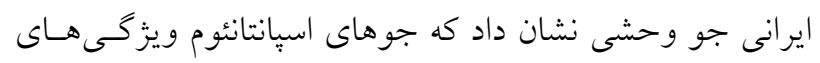

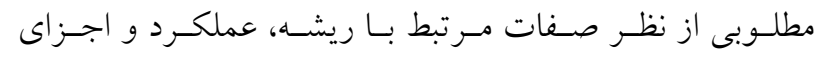

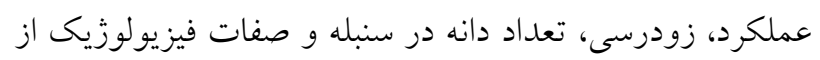

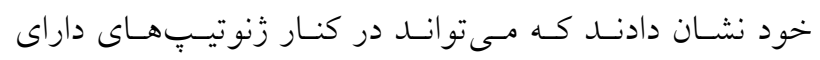

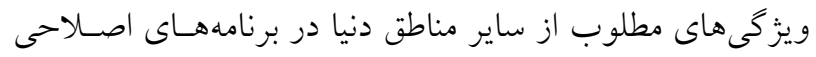

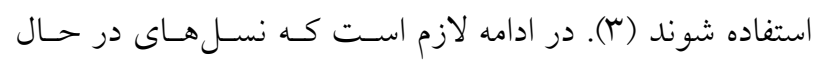

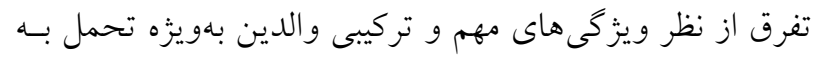

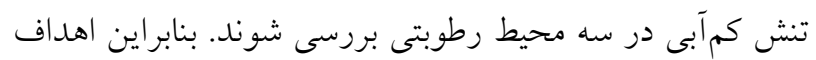
اين يزوهش عبارتند از: () بررسى تنوع زنتيكى در لاينهاى Fr

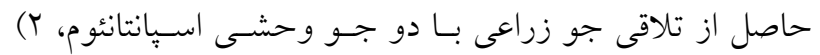

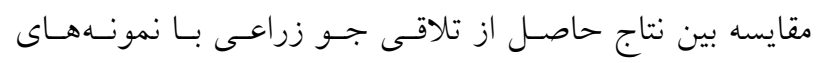

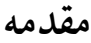

جو زراعى با نام علمى .Hordeum vulgare L متعلـق بـه قبيلـه.

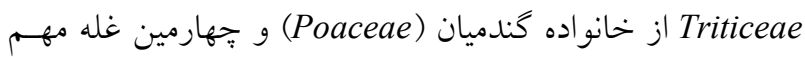

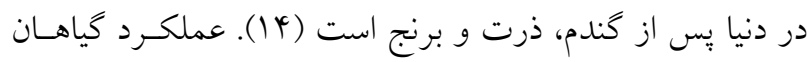

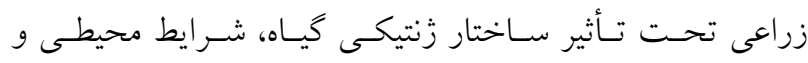

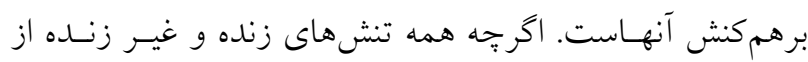

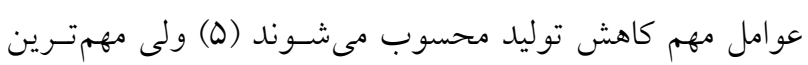

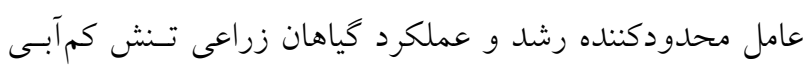
است (19). هدف از تهيه ارقامى متحمل به كمآبى معرفى ارقـام

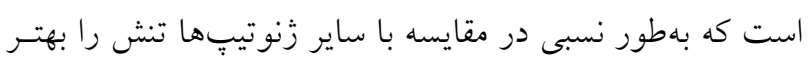

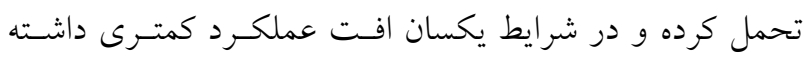

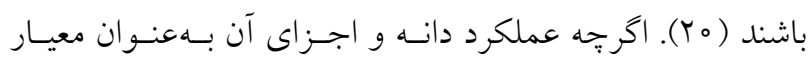

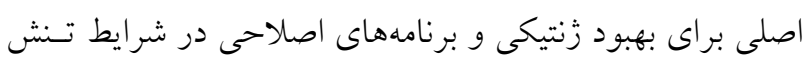

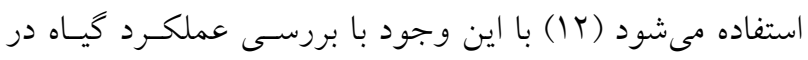

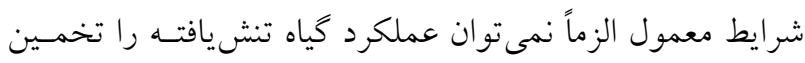

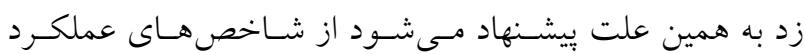

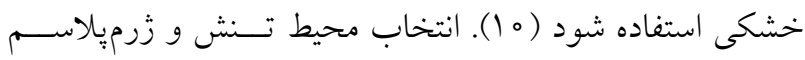

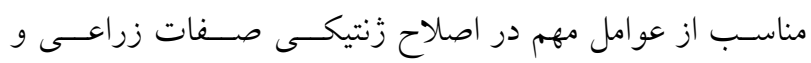

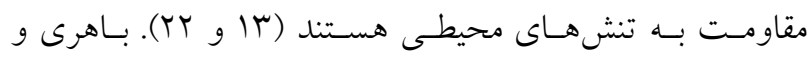
همكاران (Y) گزارش كردند تنش كـمآبسى در گيـاه جـو بهـاره

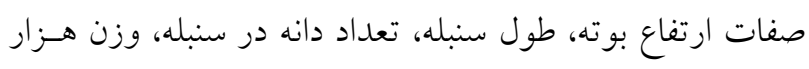

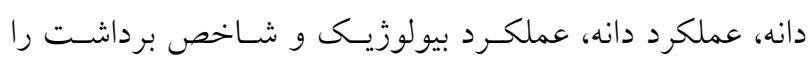

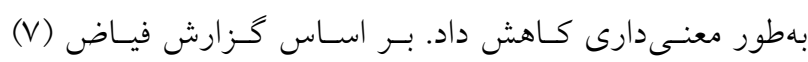

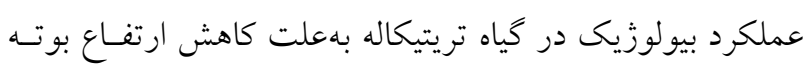
و ميزان رشد در اثر تنش كمآبى كاهش مي يابد.

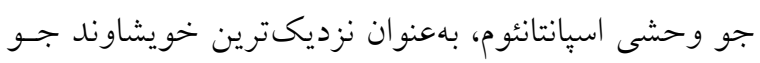

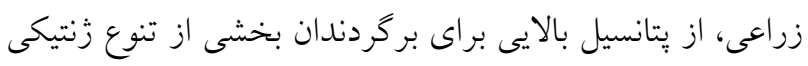

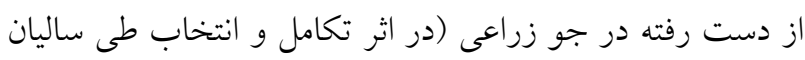

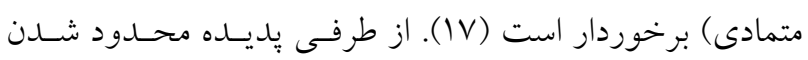

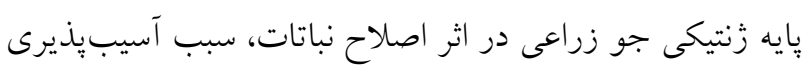

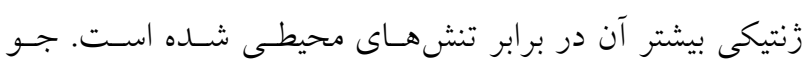

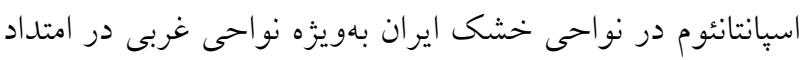




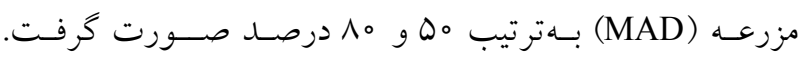

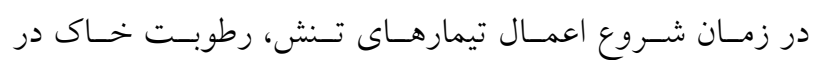

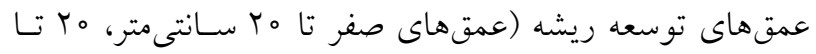

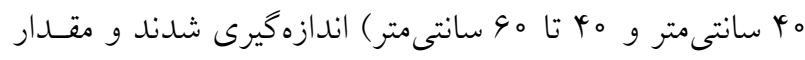

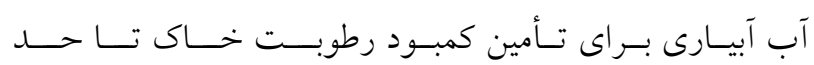

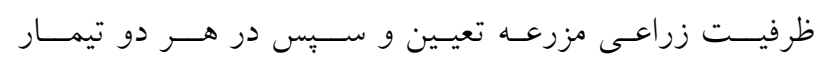

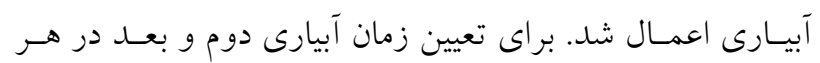

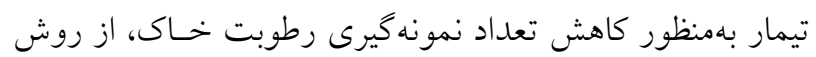

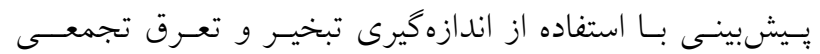

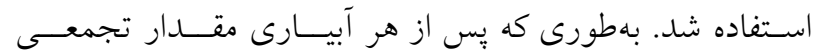
تبخيـر و تعـرق (ETc) با استفاده از دادهاى هواشناسى نجـف تهري

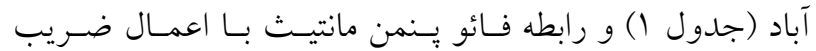
كياهى جو (برابر با يـك) طلى دوره رشــ محاسـبه شـــ (1) و

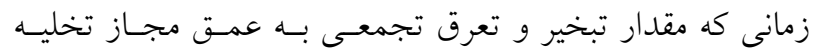

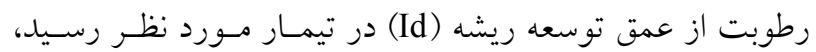

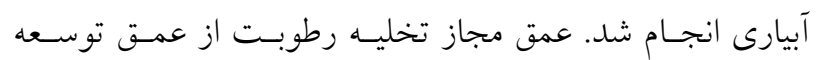
ريشه از رابطه زير محاسبه شد:

$I_{d}=(F C-P W P) \times D \times B \times M A D$

FC عمق آب مجاز براى تخليه در تيمار مورد نظر (ميلىمتر)، Id

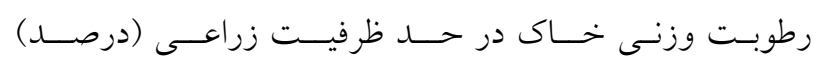

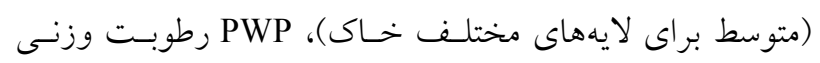

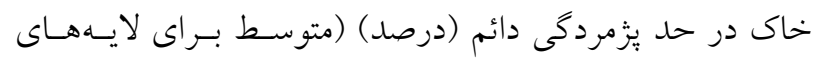

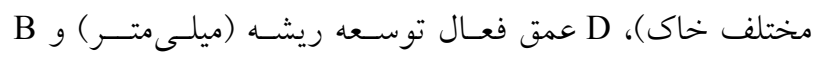

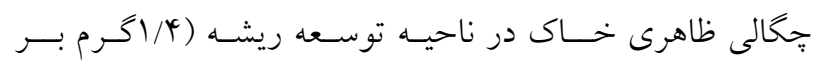

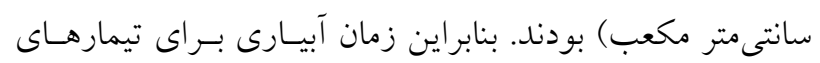

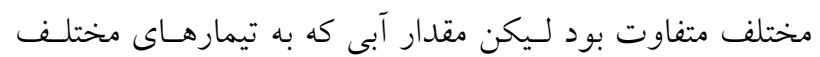

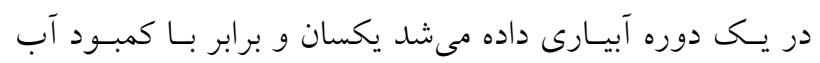

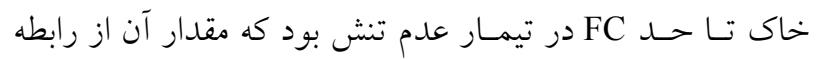

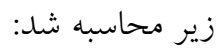

$\mathrm{I}=\left(\theta_{\mathrm{Fc}}-\theta_{\text {irri }}\right) \times \mathrm{D} \times \mathrm{B}$

در رابطه بالا

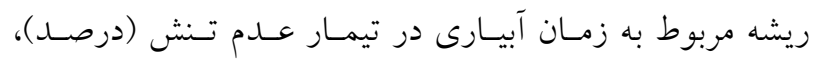

متفاوت جو وحشـى (اثـر زمينـه زنتيكسى كونسه وحشىى) و r)

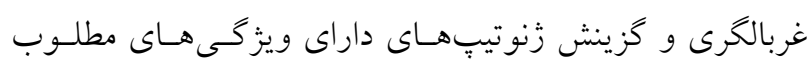
زراعى و تحمل بالا به سطوح مختلـف تـنش كــم آبسى در نتساج

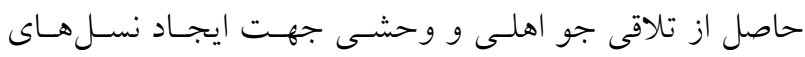
ي بيشرفتهتر

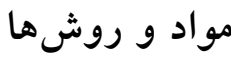

مواد زنتيكى مورد استفاده، مكان و نحوه انجام آزمايش

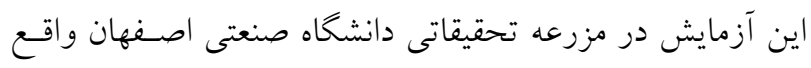

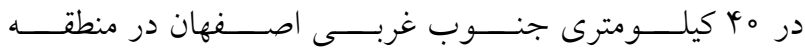
لــورى نجف آباد انجام يذيرفت. زنوتيِهـاى مـورد كشـت در

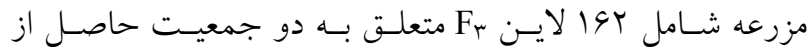

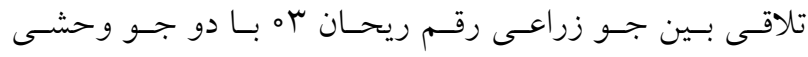

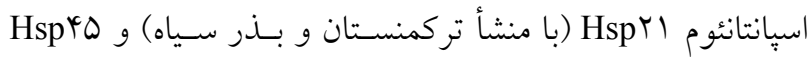
(با منشأ ايران) بودند، بهطورى كه اN لاين حاصل از تلاقى هـر نمونه جو وحشى با جو زراعى تهيه شد. جمعيتها در آبـانمـاه

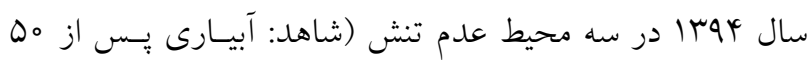

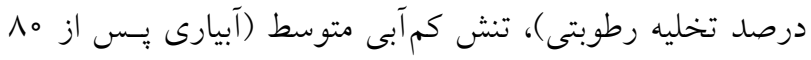

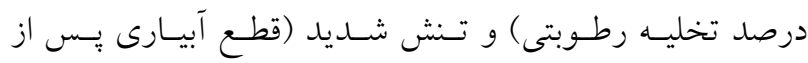

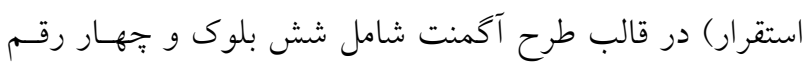

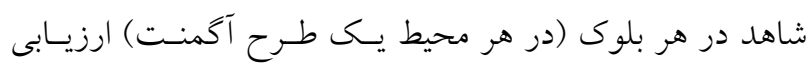

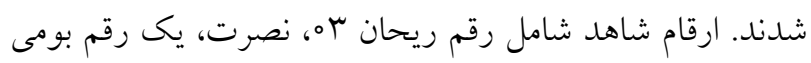

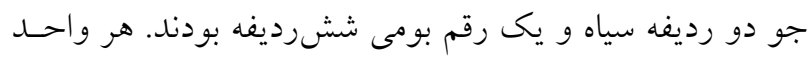

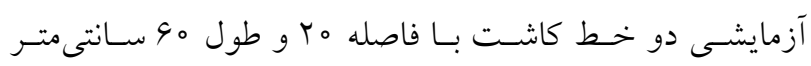

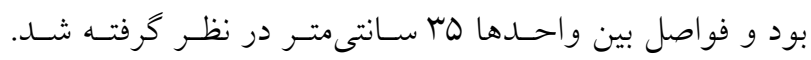
فاصله بين بوتهها در روى رديف سه سانتىمتـر در نظـر كرفتسه

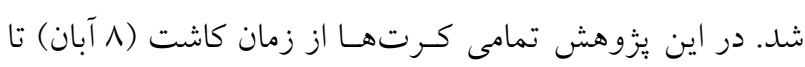

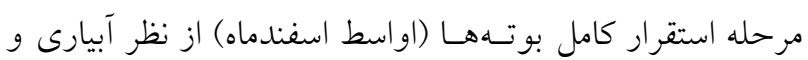
اعمال مديريتهاى زراعسى بـهـهـورت يكســان در نظـر كرفتسه

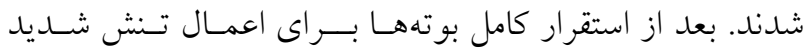

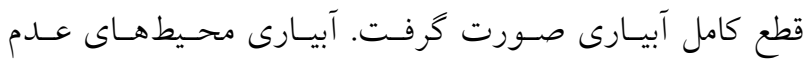

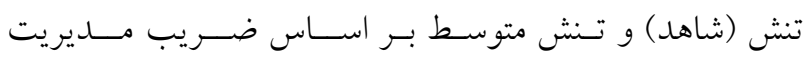


جدول ا. دادههاى هواشناسى در سال زراعى \$ه-94

\begin{tabular}{|c|c|c|c|}
\hline بيشينه دما برحسب (درجه سانتى گراد) & كمينه دما بر حسب (درجه سانتى گراد) & بارش بر حسب (ميلىمتر) & ماه \\
\hline$\mu \mathrm{M} / \Lambda$ & $V / 4$ & $14 / V$ & مهر \\
\hline$r \circ / r$ & $-1 / 4$ & 。 & آبان \\
\hline$r \mid / \Lambda$ & $-Q / r$ & $1 V / 9$ & 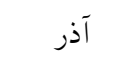 \\
\hline $\mid V / 4$ & $-\bigotimes / \wedge$ & $r / \Lambda$ & دى \\
\hline$r r / \varphi$ & $-Q / r$ & $\circ / 4$ & بهمن \\
\hline 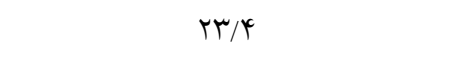 & $\circ$ & 14 & | اسفند \\
\hline$\mu_{0} / \varphi$ & $r / \Lambda$ & TS/A & 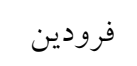 \\
\hline$\mu y / 4$ & $9 / 1$ & $r / \varphi$ & ارديبهشت \\
\hline rN/9 & 10 & $\circ$ & خ خرداد \\
\hline TG/AY & $1 / 9 \pi$ & $\Lambda / \Lambda \Lambda$ & ميانخين \\
\hline
\end{tabular}

I عمق خالص آبيارى (ميلى متـر)، حسـ ظرفيـت زراعسى (درصــ)، D عمـق فعـال توسـعه ريشـهـ

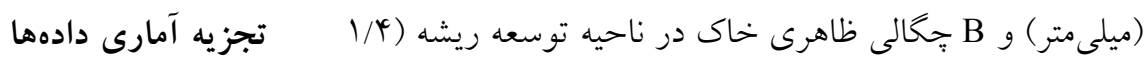
تجزيـه واريـانس بــراى ارقـام شـاهد در سـه محسيط رطـوبتى كرم بر سانتى متر مكعب) است. بهصورت جداكانه با اسـتفاده از نــرمافـزار SAS v9.4 صـورت كرفت و سبس تصحيح ميانكين هر يك از بلوكها در صـورت صفات مورد بررسى و جُخونگى اندازه گيرى نياز اعمال شـد. ميـانخينهـاى تصـحيح شــده بـراى اسـتخراج صفات فنولوزيك (روز تا سنبلهدهى و روز تا رسيدكى آمارههاى توصيفى، شاخص هاى تحمـل بـه كـمآبسى و مقايسـه فيزيولوزيك) بههمراه صفات مورفولوزيك شامل ارتفاع بوته، ميـانخين صـفات مختلـف بـه روش حسـداقل تفـاوت معنسى دار تعداد دانه در سنبله، طول سنبله، وزن صد دانه بر اساس ميانگين SAS در سـطح احتمـال هـ/ (LSD) ها -1 بوته بهصورت تصادفى از هر واحد آزمايشى (يلات) استفاده شد. بهمنظور براورد ارتباط شاخص تحمـل بـهـ تــش و استفاده شد. عملكرد دانه كه وزن كل دانهاى برداشت شده در

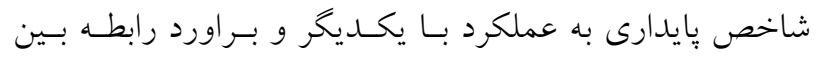
صفات از ضرايب همبستكى استفاده شد. براى ترسيم باىيـلات

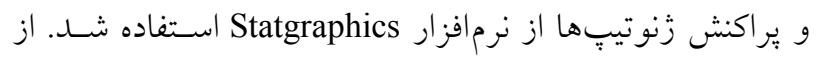
تجزيه به مؤلفهها اصلى نيز بهمنظور كاهش حجم ابعـاد دادههـا، تحليل و تفسير الكوهاى براكندگى در بين دادهها استفاده شد. هر يُات بود. با توجه به اينكه در اين مطالعه زنوتيبها در سه محيط رطـوبتى بررسى شدند، شاخص تحمل به تـنش (^) (YSI) (Y) بهمنظور (STI)

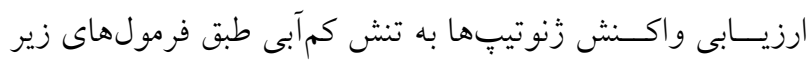
براى هر سـطح تنش به صورت جداگانه محاسبه شد.

$$
\mathrm{STI}=(\mathrm{Yp} \times \mathrm{Ys}) / \mathrm{Y}^{2}{ }_{\mathrm{mp}}
$$

نتايج و بحثث $\quad$ YSI= $Y_{S} / Y_{P}$

\section{آمارههاى توصيفى و ميزان تنوع}

نتيجه آمارههاى توصيفى صفات مشاهده شده در نتساج حاصـل از شرايط تنش، بدون تنش و Ymp ميانخين عملكرد زنوتيـٍِهـا در 
جدول r. آمارههاى توصيفى در اN لاين حاصل از تلاقى رقم ريحان به با جو وحشى ISPYI در سه محيط رطوبتى عدم تنش، تنش كمآبى متوسط و تنش كم آبى شديد

\begin{tabular}{|c|c|c|c|c|c|c|}
\hline ضريب تنوع فنو تييى & انحر اف معيار & ميانخين & دامنه تغييرات & بيشينه & كمينه & متغير \\
\hline & & & & & & عدم تنش \\
\hline$T / M V$ & $r / 09$ & $149 / 90$ & IV & 101 & $|4|$ & روز تا ظهور سنبله \\
\hline $1 / 79$ & $r / 94$ & $r \circ r / \Lambda r$ & 10 & $r \circ \Lambda$ & 191 & روز تا رسيدگى \\
\hline N/VG & $\Lambda / r I$ & $9 r / 10$ & ra & 110 & Ve & ارتفاع گياه (cm) \\
\hline IY/VG & $1 / 01$ & $9 / 90$ & $4 / 90$ & $9 / 10$ & $4 / \Delta \circ$ & طول سنبله (cm) \\
\hline$r q / 9 \mu$ & $\mid Q / 4 V$ & $r q / \circ D$ & $\Delta \Delta$ & vQ & $r_{0}$ & تعداد دانه درسنبله \\
\hline$T V / \Psi \Lambda$ & $r$ rq/qT & $\mid Y \circ O / D D$ & IVVq & TEYA & 999 & عملكرد بيولوزيك (g/m \\
\hline$T Y / O Y$ & $\circ / \mathrm{VV}$ & r/Or & $r / r q$ & $Q / / \Lambda$ & $1 / 19$ & وزن صد دانه (g) \\
\hline TM/TV & $I V \circ /{ }_{Y}$ & $011 / A V$ & QTHNG & $11 V Y / 09$ & $r \Delta \circ / \Lambda$ & عملكرد دانه (g/m \\
\hline \multirow[t]{2}{*}{ IY/Ar } & $\circ / 94$ & OKT & $\circ / \Delta \Delta$ & $\circ / \mathrm{VV}$ & $\circ / Y_{1}$ & شاخص برداشت \\
\hline & & & & & & تنش كمآبى متوسط \\
\hline $1 / 91$ & $r / \wedge Q$ & $14 \wedge / q_{0}$ & 11 & 104 & IKr & روز تا ظهور سنبله \\
\hline $1 / 14$ & $T \mu_{0}$ & $r 0|/ 4|$ & 9 & $r \circ V$ & 191 & روز تا رسيدگى فيزيولوزيك \\
\hline $19 / 0 r$ & $10 / 0 \mathrm{~V}$ & $94 / 90$ & $\Delta S$ & $9 V$ & 4 & ارتفاع كياه (cm) \\
\hline $\mid N / 9 V$ & $1 / 09$ & $0 / 9 \Lambda$ & $\Delta$ & $\wedge$ & $r$ & طول سنبله (cm) \\
\hline$r \circ / r q$ & $1 \pi / 10$ & $M T / G 4$ & 49 & gr & 14 & تعداد دانه درسنبله \\
\hline$r \wedge / \wedge)$ & $r \mid 0 / 49$ & $V \& V / a T$ & 1101 & 1001 & 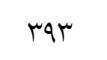 & عملكرد بيولوزيك (g/m ) \\
\hline rI/Or & $0 / 91$ & $\Upsilon / \Lambda$ & $r / \Delta \Lambda$ & $\Delta / \Delta Y$ & $1 / 99$ & وزن صد دانه (g) \\
\hline$M / N 4$ & $90 / 04$ & TAM/GT & $Y \circ Q / V Y$ & DTE/VG & $119 / \circ V$ & عملكرد دانه (g/m \\
\hline $10 / 0 \wedge$ & $\circ / \circ \Delta$ & $\circ \mu V$ & $0 / \pi$ & $\circ / 0 \circ$ & $0 / T 9$ & شاخص برداشت \\
\hline M l &.$/ 19$ & $\circ / \Delta \wedge$ &.$/ 9 V$ & $1 / 19$ & $0 / T_{1}$ & YSI \\
\hline \multirow{2}{*}{$49 / 94$} & $\circ /{ }_{\Lambda}$ & $\circ / \Delta V$ & $1 / K Y$ & $1 / 91$ &.$/ 19$ & STI \\
\hline & & & & & & تنش كم آبى شديد \\
\hline $1 / \wedge 1$ & $r / V_{0}$ & $149 / \circ r$ & IT & 100 & $1 \mathrm{kr}$ & روز تا ظهور سنبله \\
\hline $1 / 04$ & $r / \circ Q$ & $19 V / 1 T$ & $\wedge$ & $r 01$ & 194 & روز تا رسيدگى \\
\hline $1 V / 09$ & $1 / 49$ & $\nvdash / / \Gamma^{\circ}$ & pr & $v \Delta$ & m & ارتفاع (cm) \\
\hline $10 / \mathrm{VV}$ & $\circ / 19$ & $0 / 99$ & $4 / 90$ & $\Lambda / 10$ & $r / \omega_{0}$ & طول سنبله (cm) \\
\hline YT/MN & $\mid r / 4 r$ & $M I / 9 \Lambda$ & Qr & 99 & 14 & تعداد دانه در سنبله \\
\hline$\mu \circ / 01$ & IVT/VQ & $\Delta V Q / G Y$ & 119 & $10 Y 9$ & rir & عملكرد بيولوزيك (g/m \\
\hline $10 / 0 r$ & $\circ / 4 V$ & $\Gamma / 10$ & T/T & $r / r q$ & $T / I V$ & وزن صد دانه (g) \\
\hline$r \mu / T r$ & $V r / 01$ & $r \mid r / 90$ & $r V Y / r l$ & KYQ/DG & VT/R & عملكرد دانه (g/m \\
\hline $19 / 11$ & $0 / 04$ & $\circ M V$ & $\circ / \pi V$ & $\circ / Q V$ & $\circ / Y_{0}$ & شاخص برداشت \\
\hline$r q / 11$ &.$/ 10$ & okt & $\circ / \wedge \Delta$ & $0 / 99$ &.$/ 14$ & YSI \\
\hline FV/Tr & $0 / r_{0}$ & OKT & O/AY & $\circ / 90$ & $0 / 14$ & STI \\
\hline
\end{tabular}

ضريب تنوع فنوتييى بهترتيـب بـراى صـفت روز تـا رسـيدگى و تعداد دانه در سنبله بود (جدول بو س). ضريب تنوع بالايى بـراى

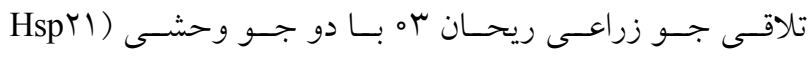
و Hsp HQD نشان داد كه در هر دو جمعيـت كمتـرين و بيشـترين 
جدول r. آمارههاى توصيفى در ای لاين حاصل از تلاقى رقم ريحان به با جو وحشى HSPYO در سه محيط رطوبتى عدم تنش، تنش كمآبى متوسط و تنش كمآبى شديد

\begin{tabular}{|c|c|c|c|c|c|c|}
\hline ضريب تنوع فنو تييى & انحر اف معيار & 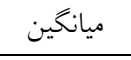 & دامنه تغييرات & بيشينه & كمينه & متغير \\
\hline & & & & & & عدم تنش \\
\hline$r / / \circ$ & $r / 10$ & $149 / v 0$ & ir & 109 & 14 & روز تا ظهور سنبله \\
\hline $1 / 00$ & $Y / I V$ & ro9/0Y & ir & rlo & 191 & روز تا رسيدگى \\
\hline $11 / 44$ & $10 / \pi r$ & $\Lambda 9 / \Gamma \Delta$ & $0 \circ / 0 \circ$ & $11 \% / 10$ & re/9o & ارتفاع كياه (cm) \\
\hline$|N / 4|$ & $1 / \pi$ & V/RG & $9 / V_{0}$ & $11 / r_{0}$ & 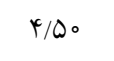 & طول سنبله (cm) \\
\hline$\kappa+/ \circ D$ & $19 / \pi 1$ & $r Q / \circ r$ & $v^{r}$ & $9 \pi$ & $r_{0}$ & تعداد دانه درسنبله \\
\hline$Y \Lambda / \Delta \Lambda$ & KYN/Yr & $|r| N / \circ V$ & leva & $r \circ 10$ & ors & عملكرد بيولوزيكى (g/m) \\
\hline $1 N / G 4$ &.$/ 09$ & $r / 19$ & t/Mt & $k / 4 k$ & T/M & وزن صد دانه (g) \\
\hline MI/QF & $\mid k F / k T$ & rOV/AS & $\Delta Q T / F V$ & VVT/MT & $110 / 99$ & عملكرد دانه (g/m \\
\hline \multirow[t]{2}{*}{$M / \Gamma V$} & $0 \% 9$ & $\circ / M V$ & $0 / \mu x$ & o/Qr & $\circ / 1 \wedge$ & شاخص برداشت \\
\hline & & & & & & تنش كمآبى متوسط \\
\hline $1 / 94$ & $r / M$ & $\mid Y N / Y T$ & 19 & 100 & 149 & روز تا ظهور سنبله \\
\hline $1 / \pi r$ & $r / Y q$ & $r 01 / V 9$ & ir & rII & 199 & روز تا رسيدگى فيزيولوزيك \\
\hline $1 N / 94$ & $10 \pi q$ & $\Delta 9 / 1 \Lambda$ & \&V & $\Lambda^{\kappa}$ & rv & ارتفاع گياه (cm) \\
\hline$r Y / 91$ & $1 / T V$ & $Q / \Delta \Lambda$ & 4 & $\wedge$ & r & طول سنبله (cm) \\
\hline MG/4G & $\mid r / 0 r$ & $m / \circ q$ & Q० & 99 & 19 & تعداد دانه درسنبله \\
\hline 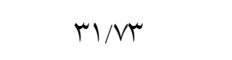 & $T \ll \& / 9 \Lambda$ & VVV/rY & 1019 & lifq & rar & عملكرد بيولوزيك (g/m ) \\
\hline 19/0r & $\circ / \Delta \Delta$ & r/A & $r / Q r$ & $r / \circ \wedge$ & $1 / 00$ & وزن صد دانه (g) \\
\hline (T/lQ & $101 / \mu_{0}$ & $r \circ \Delta / \Delta Q$ & $K Y N / \circ D$ & $\Delta \wedge 1 / \Lambda \Lambda$ & 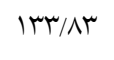 & عملكرد دانه (g/m \\
\hline$|Y / T|$ & $\circ / \circ \Delta$ & $\circ / \pi q$ & $0 / T^{4}$ & $\circ / \Delta r$ & $0 / 49$ & شاخص برداشت \\
\hline$K Y / 9 \Lambda$ & $0 / \pi 1$ & $\circ / N r$ & $1 / 4 k$ & $1 / 94$ & $\circ / T_{1}$ & YSI \\
\hline \multirow{2}{*}{$\Delta r / 1 Q$} & $\circ / \pi \Delta$ &.$/ 91$ & $1 / 90$ & I/VQ &.$/ 14$ & STI \\
\hline & & & & & & تنش كم آبى شديد \\
\hline$r$ & $T / 9 V$ & $\mid Y N / T_{0}$ & IV & 100 & IrA & روز تا ظهور سنبله \\
\hline$\circ / N r$ & $1 / 40$ & $19 V / 09$ & 4 & Yoo & 194 & روز تا رسيدگى \\
\hline $\mid V / \backslash \Lambda$ & $\Lambda / \circ 9$ & $F V / I 1$ & ra & vi & re & ارتفاع (cm) \\
\hline IV/IF & $1 / 04$ & $9 / 11$ & Y/VT & $9 / 10$ & $r / T V$ & طول سنبله (cm) \\
\hline $4 \varphi / V$ & $I V / \cdot D$ & $r 4 / 0 \circ$ & $\Delta \wedge$ & VY & 14 & تعداد دانه درسنبله \\
\hline$r \omega / 90$ & rQQ/9N & $V T N / T q$ & ITVY & 1099 & rqY & عملكرد بيولوزيكى (g/m) \\
\hline $14 / 94$ & D/MT & T/AS & r & $r / T$ & T/T & وزن صد دانه (g) \\
\hline $49 / 91$ & 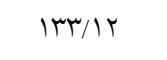 & TAT/TO & $\Delta V r / a r$ & 999199 & QT/VG & عملكرد دانه (g/m \\
\hline TY/TH & $\circ / \circ \wedge$ & $\circ / M V$ & $0 / 49$ & $\circ / 09$ & $0 \% 4$ & شاخص برداشت \\
\hline$V 1 / 01$ & $\circ / 01$ & $\circ / V Y$ & $r / \Lambda 1$ & $r / 99$ & $0 / I V$ & YSI \\
\hline $99 / \mathrm{VI}$ & $0 / 4 y$ & $0 / 44$ & $r / \circ V$ & T/K & $0 / 19$ & STI \\
\hline
\end{tabular}

بيشتر بـود (جــول Y). ميـانخين روز تـا ظهـور سـنبله و روز تـا رسيدگى در محيط تنش شديد در هر دو جمعيـت كمتـر از عـدم
دو شاخص STI و YSI، در هر دو محيط تنش متوسط و شــيد

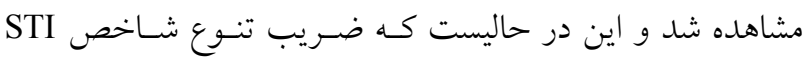




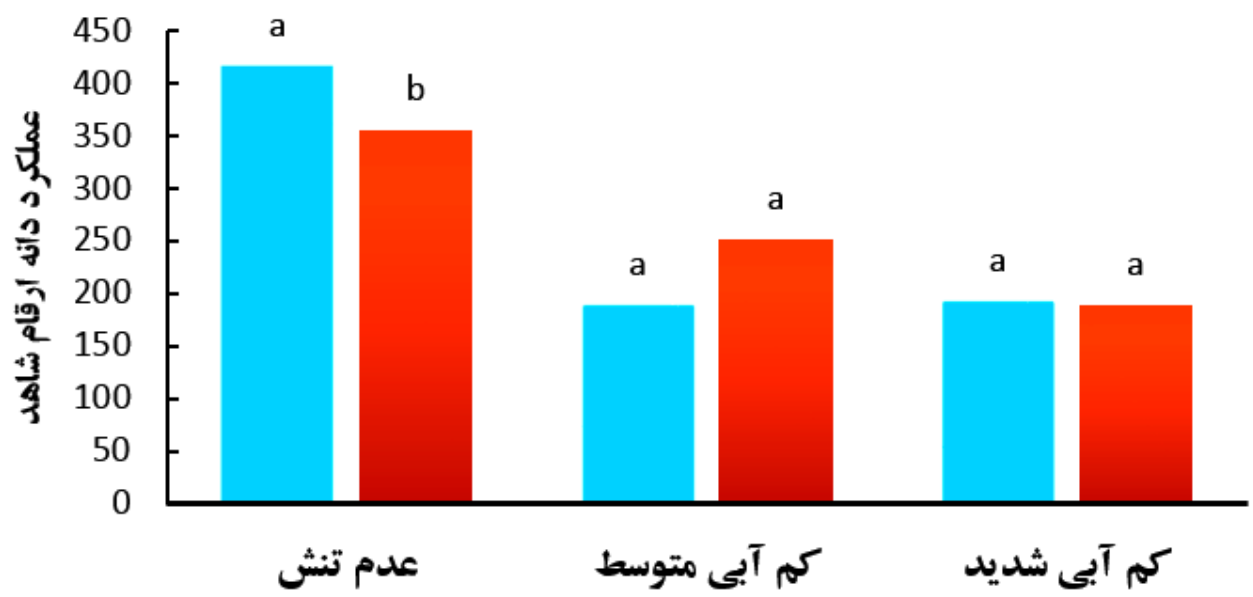

HSP21 HSP45

شكل ا. مقايسه ميانكين عملكرد دانه (گرم در مترمربع) ارقام شاهد در دو جمعيت F3 حاصل ازتلاقى جو زراعى با جو وحشى اسپانتائوم. در هر تيمار، تفاوت بين دو جمعيت داراى حرف مشترك از نظر آمارى بر اساس روش LSD در سطح بنج درصد معنىدار نيست.

از جمعيت ديخر بود و در بقيه صفات نسبت بـه جمعيـت ديخـر

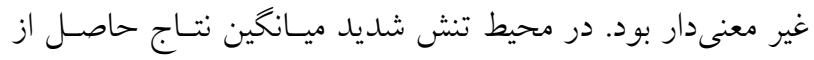

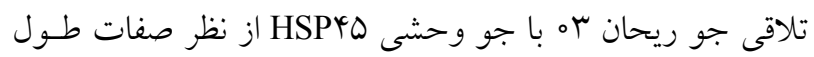

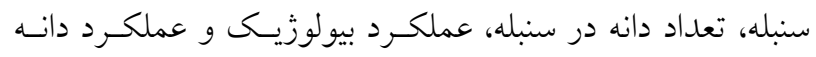

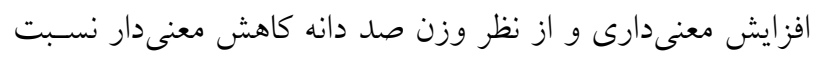

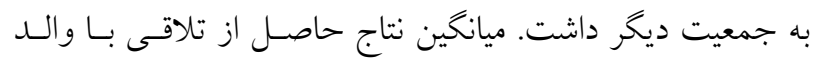

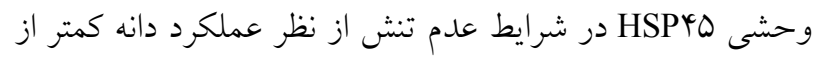
جمعيت ديخر بود ولى در تنش شديد ميانكين عملكرد آن بيشـتر

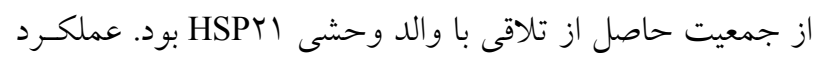

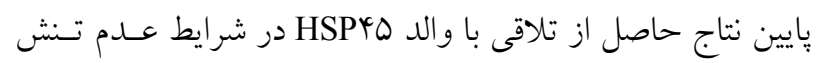

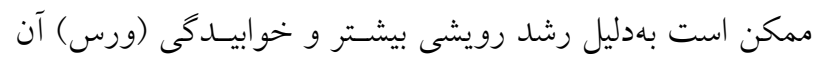

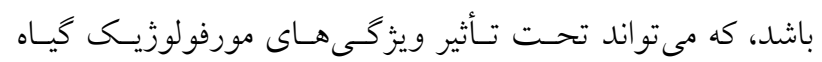

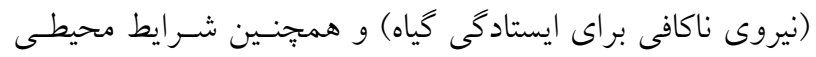

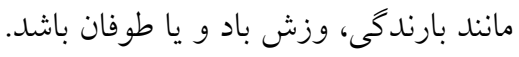

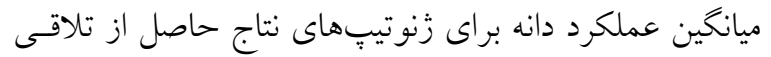
با والد HSPYI در شرايط عدم تنش، تنش متوسط و تنش شـديد

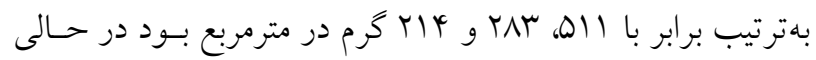

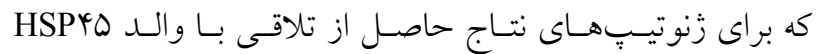

تنش و تنش متوسط بود. اين كاهش مىتوانــ بـهدليـل فـرار از

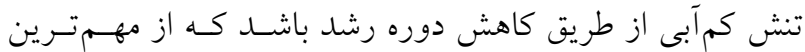

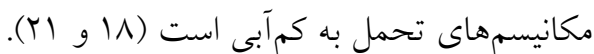
مقايسه ميانگين دو زمينه زنتيكى براى صفات مختلف

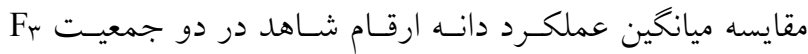
حاصل از تلاقى جو زراعى با دو كونه جـو وحشـى اســانتانئوم (شكل 1) نشان داده شده است. نتايج تجزيه مركب ارقام شـاهد

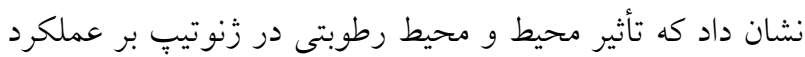
دانه در سطح ل1\% معنىدار شد (جدول نشان داده نشده است). مقايسه ميـانخين صـفات مـورد بررسى در دو جمعيـت Fr Fr

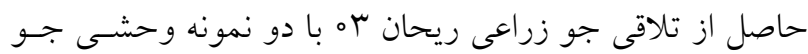

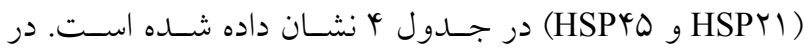
محيط عدم تنش ميانكين نتاج حاصل از تلاقى جو ريحان بَه با

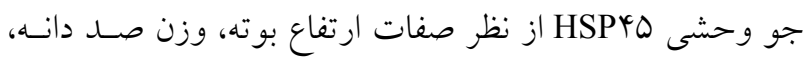
عملكرد دانه و شاخص برداشت كمتر و از نظر صـفات روز تـا

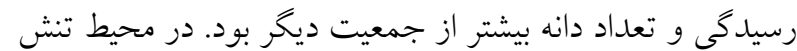

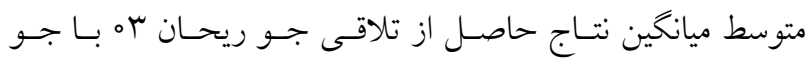

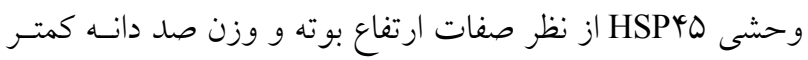


جدول f. مقايسه ميانكين دو جمعيت Fr حاصل از تلاقى دو كونه وحشى جو (HSPYI و HSPYD) با جو زراعى به تفكيك محيطهاى رطوبتى براى صفات مختلف

\begin{tabular}{|c|c|c|c|c|c|c|}
\hline \multicolumn{2}{|c|}{ تنش شديد } & \multicolumn{2}{|c|}{ تنش متوسط } & \multicolumn{2}{|c|}{ علدم تنش } & \\
\hline HSP YQ & HSP Y I & HSP Y & HSP Y I & HSP Y & HSP YI & صفات \\
\hline $1 Y \wedge / Y^{\mathrm{a}}$ & $149^{a}$ & $1 Y \wedge / Y^{a}$ & $14 \wedge / q^{a}$ & $149 / \wedge^{a}$ & $149 / 9^{a}$ & روز تا ظهور سنبله \\
\hline $19 \mathrm{~V} / 9^{\mathrm{a}}$ & $19 \mathrm{~V} / \mathrm{1}^{\mathrm{a}}$ & $r \circ 1 / \wedge^{\mathrm{a}}$ & $r \circ 1 / 4 a$ & $r \circ \varphi \mathrm{a}$ & $r \circ r / \wedge^{b}$ & روز تا رسيدكى \\
\hline 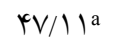 & $\uparrow \wedge / \kappa^{\mu}$ & $\Delta S / / \wedge^{b}$ & $9 \mu / 90^{a}$ & $\Lambda ৭ / \Gamma \Delta^{b}$ & $q r / \Lambda \circ a$ & ارتفاع بوته (cm) \\
\hline $9 / 11^{a}$ & $\omega / 99 b$ & $\Delta / \Delta \wedge^{\mathrm{a}}$ & $\Delta / 9 \wedge^{\mathrm{a}}$ & $V / r q a$ & $9 / 9 \circ \mathrm{a}$ & طول سنبله (cm) \\
\hline$r 4 / 0 \circ a$ & $\mathrm{MI} / 9 \wedge^{\mathrm{b}}$ & $r / \circ q^{a}$ & $\mathrm{rT/G \varphi a}$ & $\varphi Q / \circ r^{a}$ & $r q / \circ \Delta^{b}$ & تعداد دانه درسنبله \\
\hline$V Y \Lambda / \Gamma^{a}$ & $\Delta \vee Q / q^{b}$ & $V V V / T^{a}$ & $V Y V / q^{a}$ & $|r| \Lambda /\left.\right|^{a}$ & $\mid r \circ 0 / q^{a}$ & عملكرد بيولوزيك (g/mr) \\
\hline Y/Aৎb & $r / l Q^{a}$ & $T / \Lambda r^{\mathrm{b}}$ & $r / \Lambda \Lambda^{\mathrm{a}}$ & $r / 1 \varphi^{b}$ & $r / \Delta r^{a}$ & وزن صد دانه (g) \\
\hline$r \wedge r / \Psi^{a}$ & rIYa & $\mu \circ \Delta / \varphi^{a}$ & $r \wedge r / \varphi^{a}$ & $Y \Delta V / q^{b}$ & $011 / 9^{a}$ & عملكرد دانه ( \\
\hline$\circ / \mu V^{a}$ & $\circ / \mu V^{a}$ & $\circ / \mu q a$ & $\circ / \mathrm{V}^{\mathrm{a}}$ & $\circ / \mu V^{b}$ & $\circ / \mathcal{A} Y^{a}$ & شاخص برداشت \\
\hline
\end{tabular}

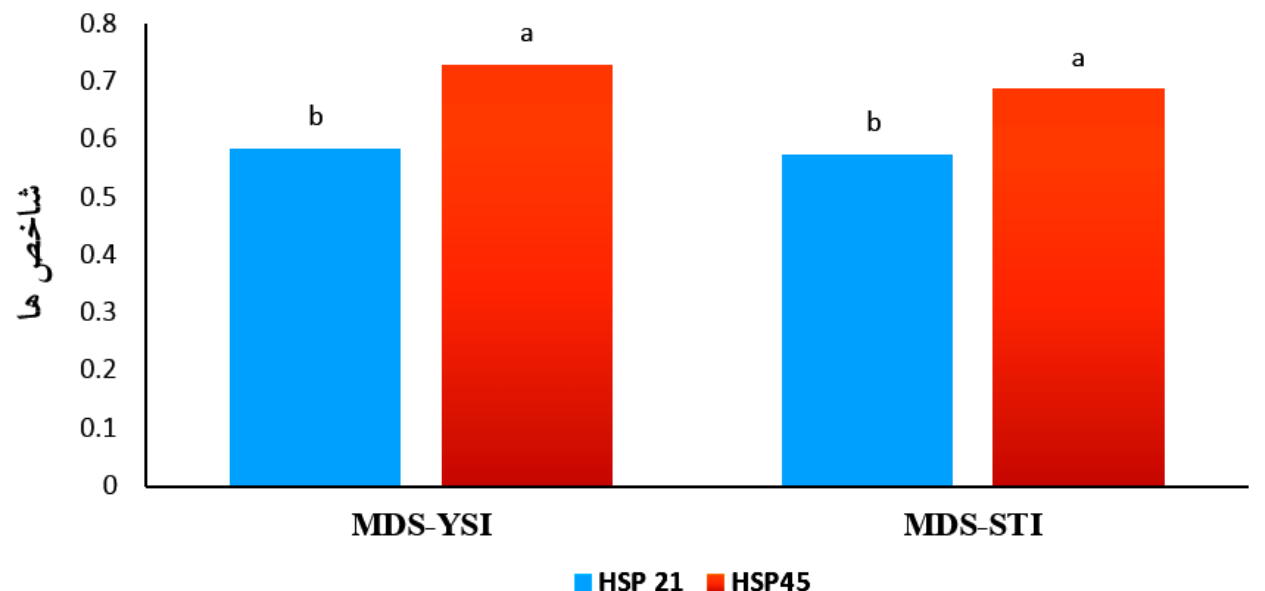

شكل Y. مقايسه ميانكين دو جمعيت F3 براى شاخص بايدارى عملكرد (YSI) و شاخص تحمل به خشكى در شرايط تنش متوسط (STI). در هر تيمار، تفاوت بين دو جمعيت داراى حرف مشترك از نظر آمارى بر اساس روش LSD در سطح بنج درصد معنىدار نيست.

ميانخين شاخص تحمل به تنش كـمـبـ (STI) و شـاخص

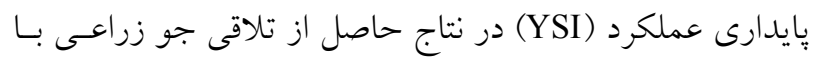
والد وحشى HSPYD در شرايط تنش متوسط و شـديد بيشـتر از

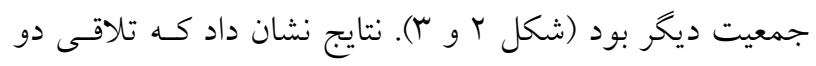

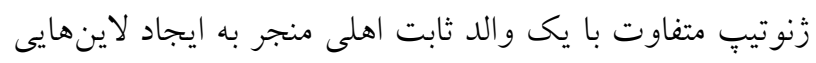

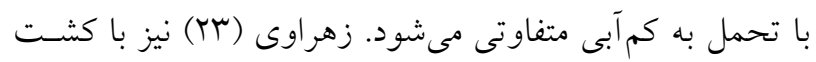

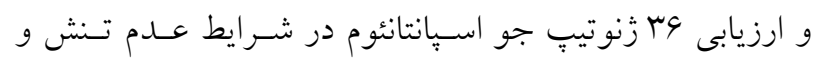

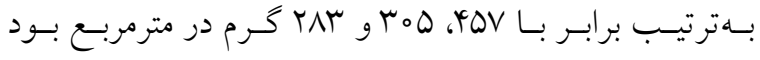

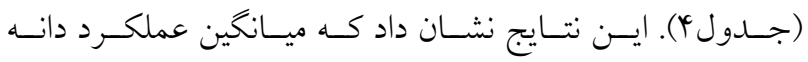

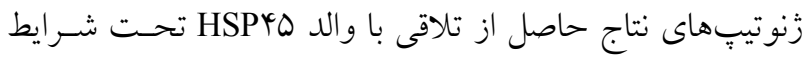

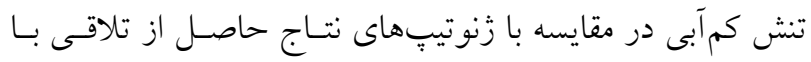

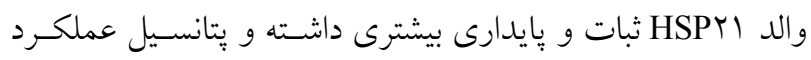

$$
\begin{aligned}
& \text { آن در شرايط تنش متوسط و تنش شديد بيشتر از جمعيـت ديخـر }
\end{aligned}
$$




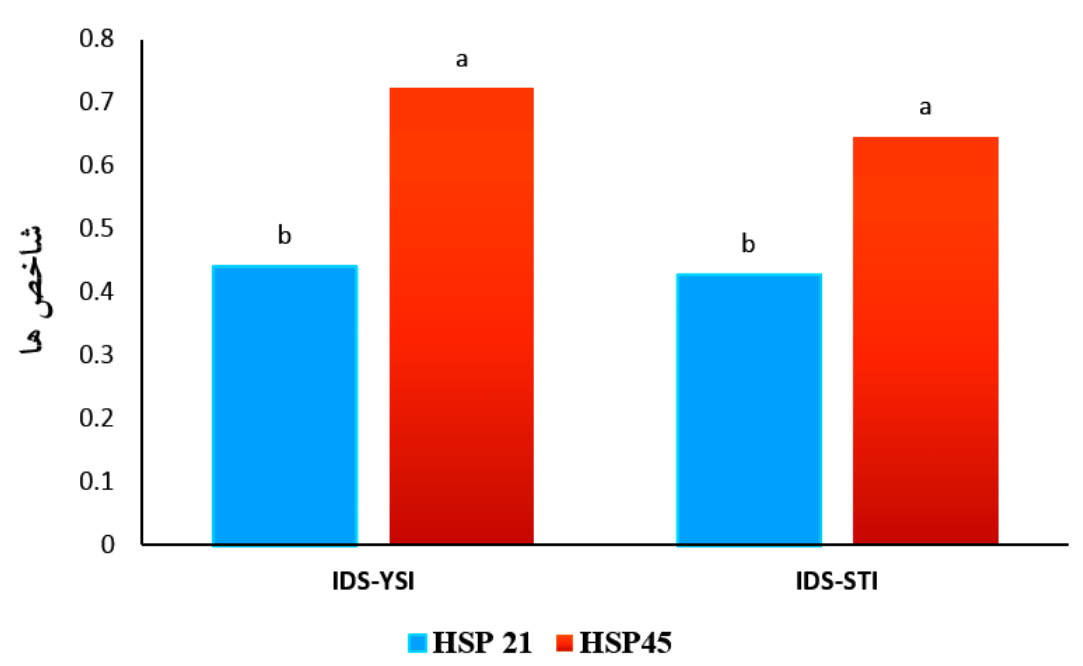

شكل r. مقايسه ميانكين دو جمعيت F3 براى شاخص پايدارى عملكرد (YSI) و شاخص تحمل به خشكى (STI) در شرايط تنش شديد.

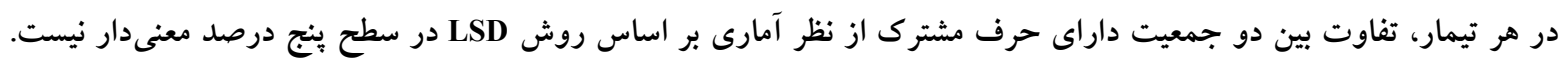

مطالعه حاضر در شرايط عدم تنش تجزيه به مؤلفهها روى 11 زنوتيب حاصل از تلاقى جو زراعى ريحان به با جو وحشى نشان داد كه دو مؤلفه اصلى و ابتـدايى HSPYI كل تغييرات را توجيه كردند (شكل أ- الف). مؤلفه اول ه/ هM درصد از كـل تغييـرات را توجيـه كـرد. ضـرايب مربـوط بـهـ عملكرد دانه، وزن صد دانه و عملكرد بيولوزيك در اين مؤلفه

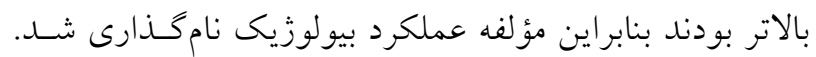

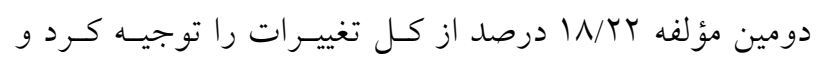
همبستخى مثبت و بالايى با صفات روز تا ظهور سـنبله و روز تا رسيدكى فيريولوزيك داشت كه مؤلفه فنولوزيك نـام نهـاده شد. در كل زنوتيِّهايى كه مقادير بالايى از نظرمؤلفهاى اول و مقادير كمى از مؤلفه دوم را دارند، مطلوب هستند. بـر ايسن

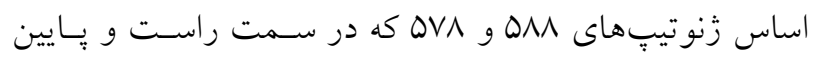

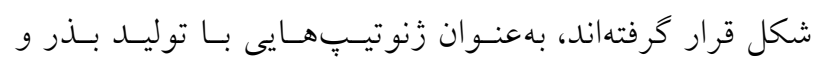
علوفه زياد و دوره فنولوزى كوتاه معرفى مىشـوند. در ديخـر

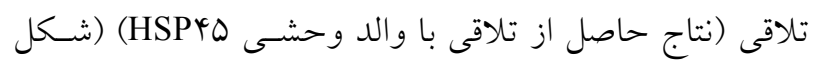

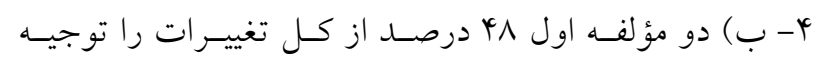
كردند. مؤلفه اول TY/VI درصد از كل تغييرات را توجيه كـرد و همبستخى مثبت و بالايى با صفات عملكرد دانـه و عملكـرد

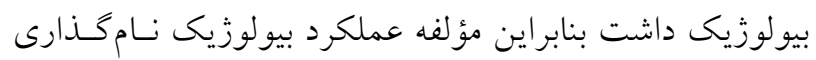
شد. دومين مؤلفه H/VY درصد كل تغييرات را توجيه كـرد و
تنش كم آبى، شاخص هـاى تحمـل بـه تــش را انـدازهذيـرى و شاخص STI را بهعنوان مناسبترين شـاخص بـر اي شناسـايى

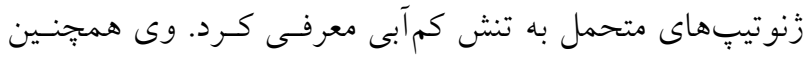

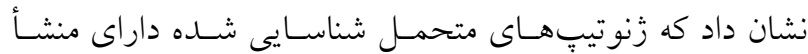

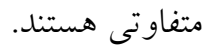
در مطالعه حاضر همبستخى ساده بين صفات نيـز محاسـبه شد (نتايج نشـان داده نشـده اسـت). بـهــور خلاصـه نتـايج ضرايب همبستخى در نتاج حاصـل از تلاقى بـا هـر دو والـد

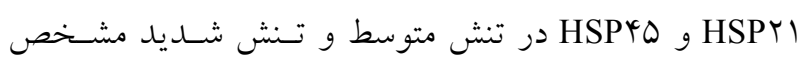
كرد كه بـين عملكـــد دانـه و صـفات ارتفـاع بوتـه، عملكـــد بيولوزيك، شاخص تحمل به كمآبى (STI) و شاخص يايدارى

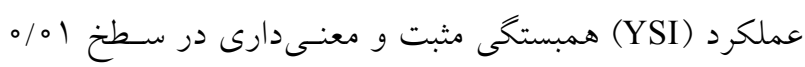
و وجود دارد.

\section{ترسيم نمودار باى يّات مؤلفههاى اصلى} استفاده از روش مؤلفههاى اصلى براى گزينش زَنوتيــهــا در شرايط محيطى مختلف بهعنو ان يك روش كارامد مطرح شــده

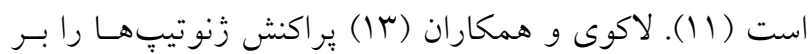

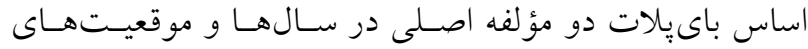
مختلـف در شـر ايط تـنش كـما آبسى و عــدم تـنش بررسـى و زنوتيِهاى بر عملكرد در هر شرايط را مشـخص كردنـد. در 

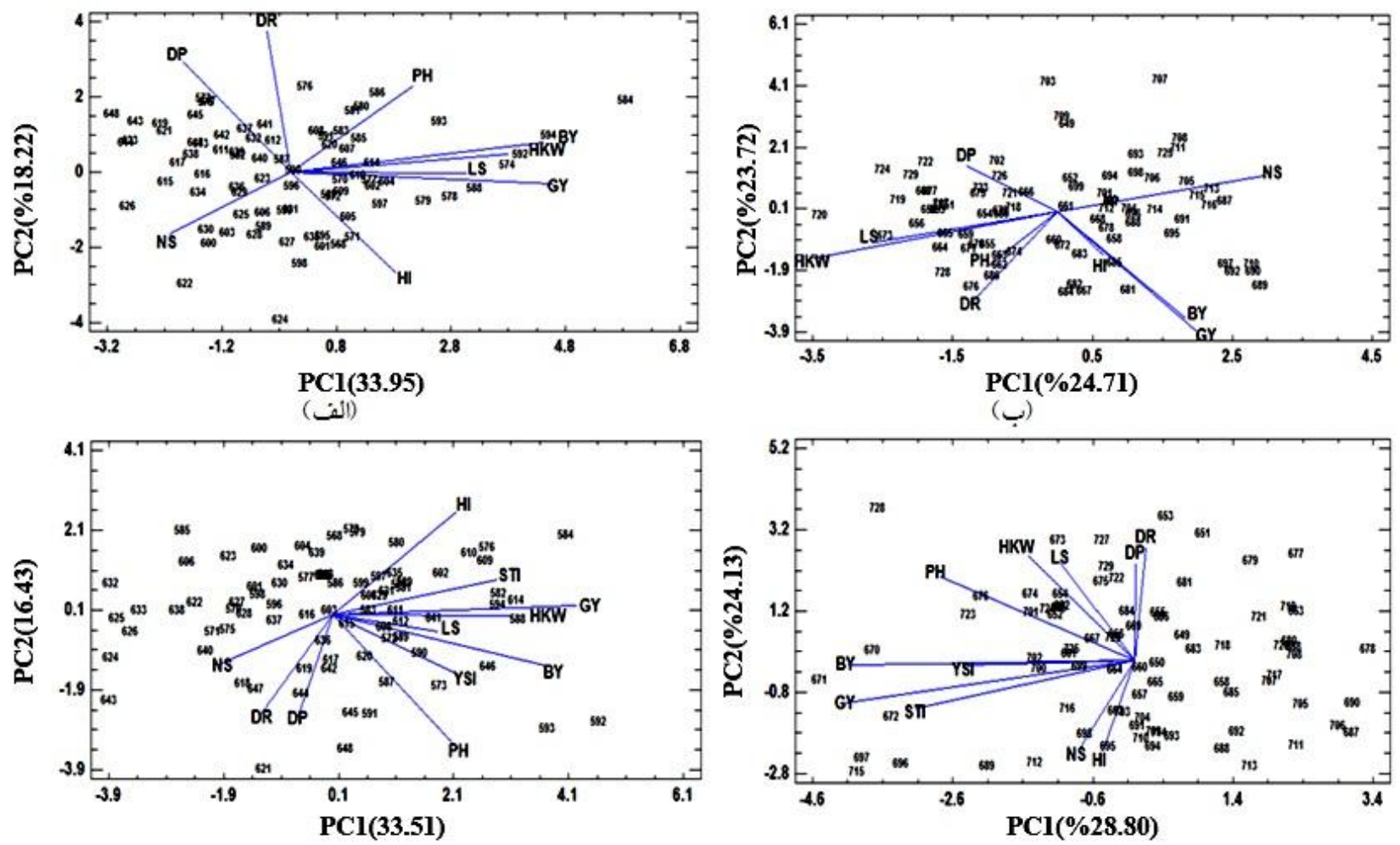

(ج)

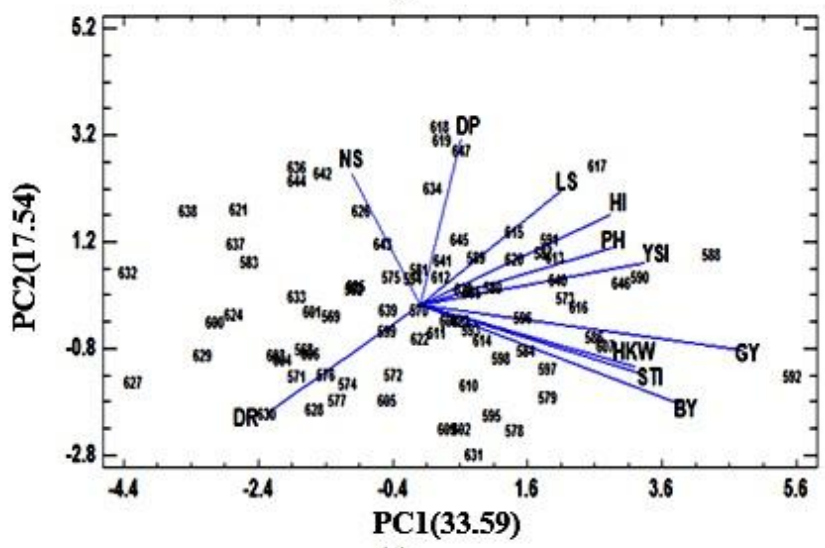

(2)

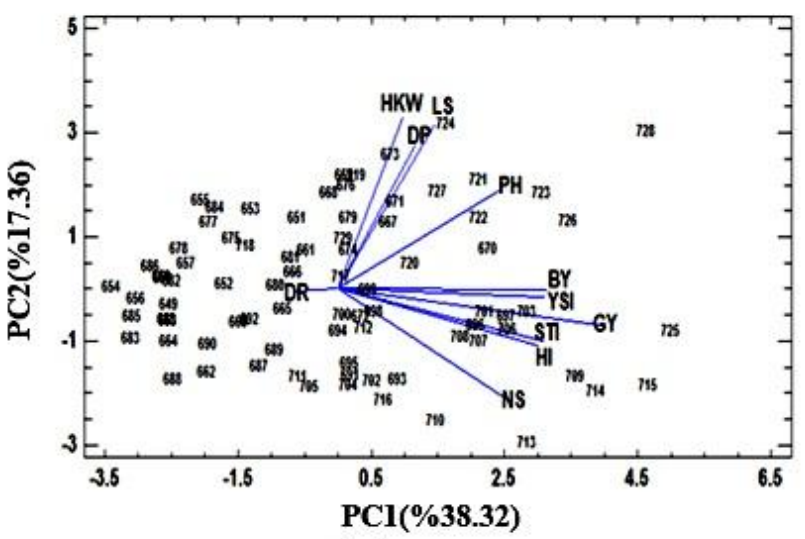

(ى)

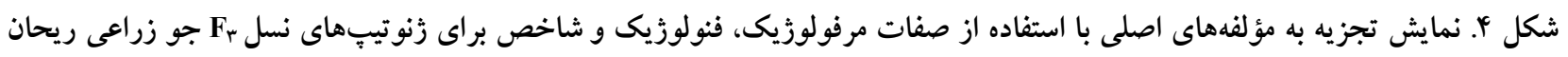

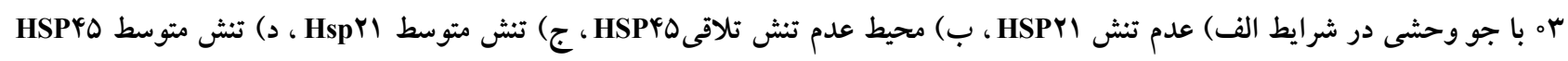

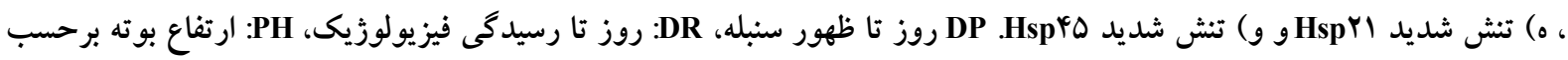

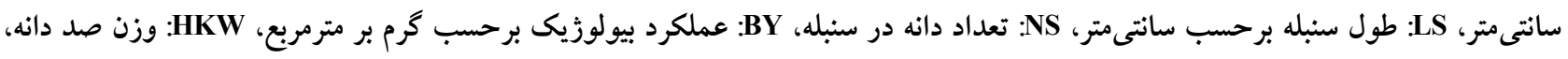

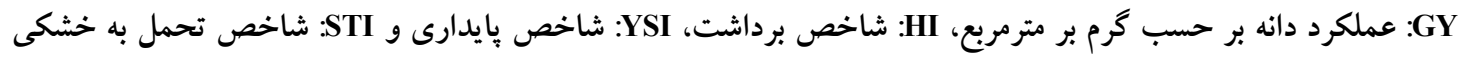

بيولوزيك بالا و دوره فنولوزى كوتاه معرفى شد. در شرايط تنش متوسط تجزيه به مؤلفها روى الرزنوتيب

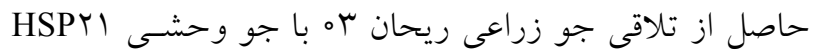

همبستكى منفى بالايى با صفات روز تا رسيدگى فيزيولوزيـى

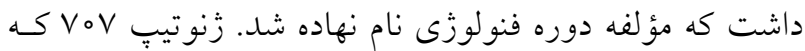

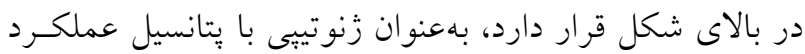


HSPYQ جمعيــــ

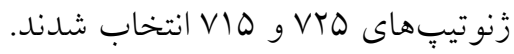

غربالكرى زنوتيبها براى تحمل به تنش خشكى

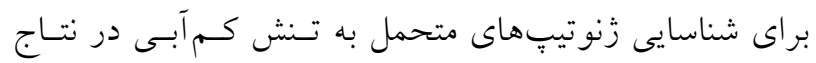

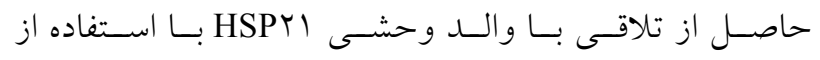
شاخص هاى تحمل به تنش، باىيلات شاخص STI (بهعنـوان شاخص تحمل) در مقابل YSI (بـهنــوان شـاخص بايسـارى)

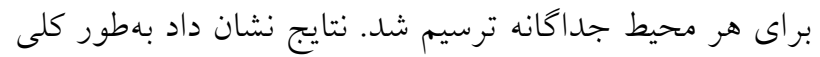
لاينهاى داراى شاخص STI بالا مقدار شـاخص YSI بـايينى دارند. در شرايط تنش متوسط (شكل ه- الف) لاينهاى سله، YSI ON بيشترى داشتند و لاين شماره Q D شاخص تحمل به خشكى

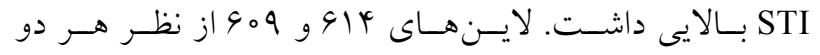
شاخص مطلوب بودند. در شرايط تنش شديد (شـكل ه- ب) بالاترين شاخص بايدارى عملكرد و شاخص تحمل به كمآبسى

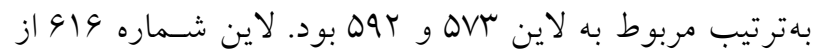
نظر هر دو شاخص در شرايط تــش شـديد برتـر بــود. بـراى شناسايى زنوتيڤٍ هاى متحمل به تنش كم آبى در نتاج حاصل از تلاقى با والد وحشى HSPYD با استفاده از شاخص هاى تحمل به تنش، باى يلات شاخص STI در مقابل YSI در شرايط تنش متوسـط ترسـيم شـد (شـكل و- الـفـ). نتـايج نشـان داد كـهـ

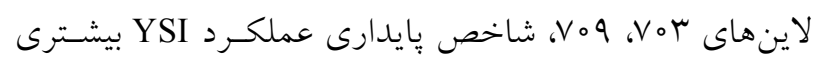

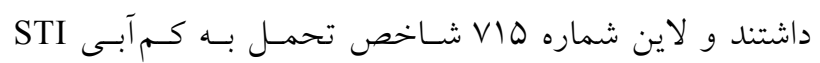
بالايى داشت. لاين او از نظر هر دو شاخص برتر بودند. در شرايط تنش شديد (شكل و- ب) بالاترين شـاخص پايسـارى عملكرد و شاخص تحمل به كم آبى بهترتيب مربوط بـه لايسن

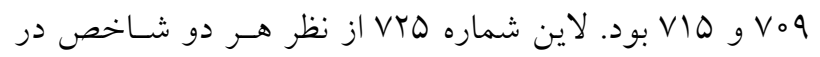

$$
\text { شرايط تنش شديد برتر بود. }
$$

مقدار بيشترشاخص YSI نشاندهنده يايدارى عملكــرد در شرايط تنش و براى شاخص STI به معنى عملكرد بـالا در دو محيط شاهد و تنش است. بنابراين لاينهايى كه از نظر هر دو
(شكل ب ج) نشان داد كه دو مؤلفـه اصـلى •ه درصــ از كـل

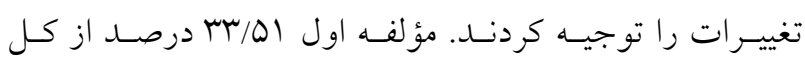

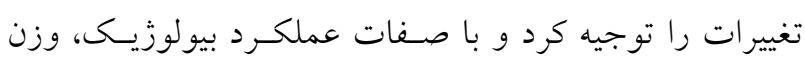
صد دانه و عملكرد دانه همبستخى مثبت و بالايى نشان دادنــ. بنابراين اين مؤلفه به نام مؤلفه عملكرد بيولوزيك نـامخــارى

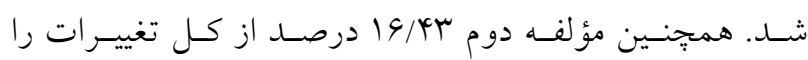
توجيه كرد و همبستخى منفى با صفات روز تـا ظهـور سـنبله، روز تا رسيدگى فيريولوزيك و ارتفاع بوته داشت كه بـر ايسن

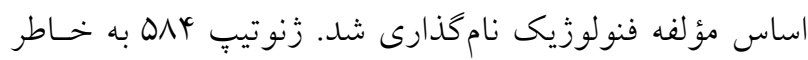
داشتن مقادير بالايى مؤلفه اول و دوم، بيشينه عملكرد و كمينه

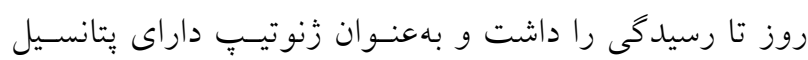
توليد اقتصادى مناسب معرفى شد. نتـاج حاصـل از تلاقى بـا

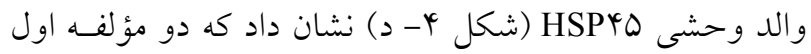

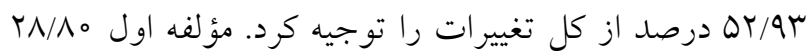
درصد از كـل تغييـرات را توجيـه كـرد و همبسـتخى منفى و بالايى با صفات عملكرد دانه، عملكرد بيولوزيك، ارتفاع بوتسه و داشت. بر اين اساس مؤلفه اول به نام عملكـــد بيولوزيــ STI

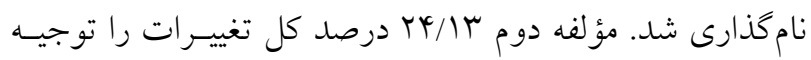

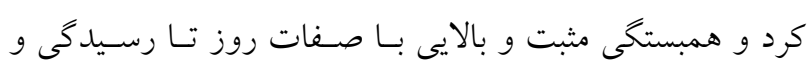
روز تا ظهـور ســبله داشـت. بنـابراين مؤلفـه دوم بـه نـام دوره

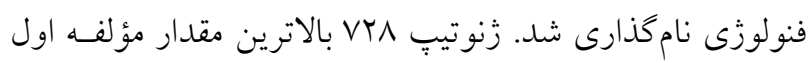
و دوم را دارد كه بهعنوان بيشـينه عملكــرد بيولوزيـك و كمينـهـ دوره فنولوزى معرفى شد. بـه همسين ترتيـب در شـرايط تسنش

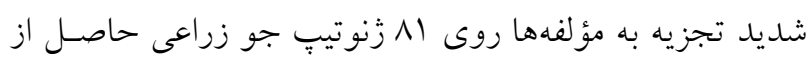

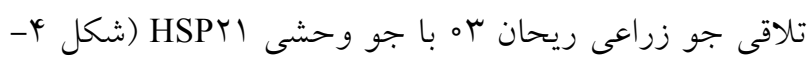

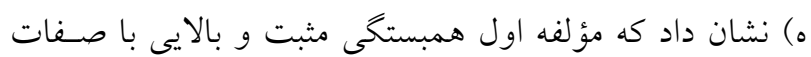
عملكرد دانه، STI و YSI دارد كه بر اين اساس مؤلفـه اول را به نام مؤلفهاى شاخص تحمل به كم آبى نام گذارى شد. مؤلفــ دوم با صفات روز تا ظهور سنبله، طول سنبله و تعداد دانـه در سنبله همبستكى مثبت و بالايى را نشـان داد و يتانسـيل توليـد بذر نام گذارى شد. همين روند در جمعيت حاصل از تلاقى با والد وحشى HSPYD (شكل عا - و) ديده شـد. در مجمـوع در 


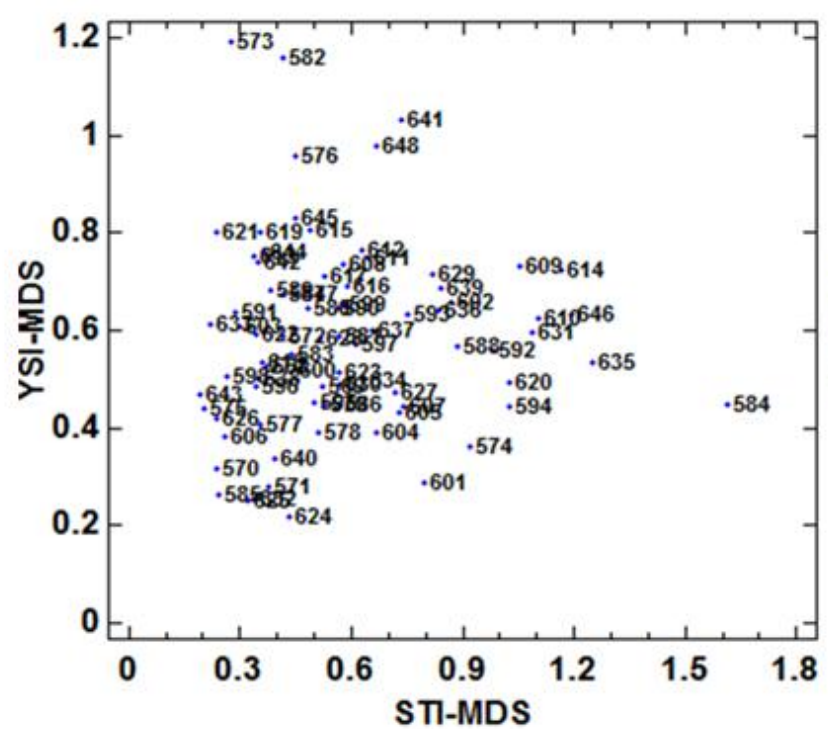

(الف)

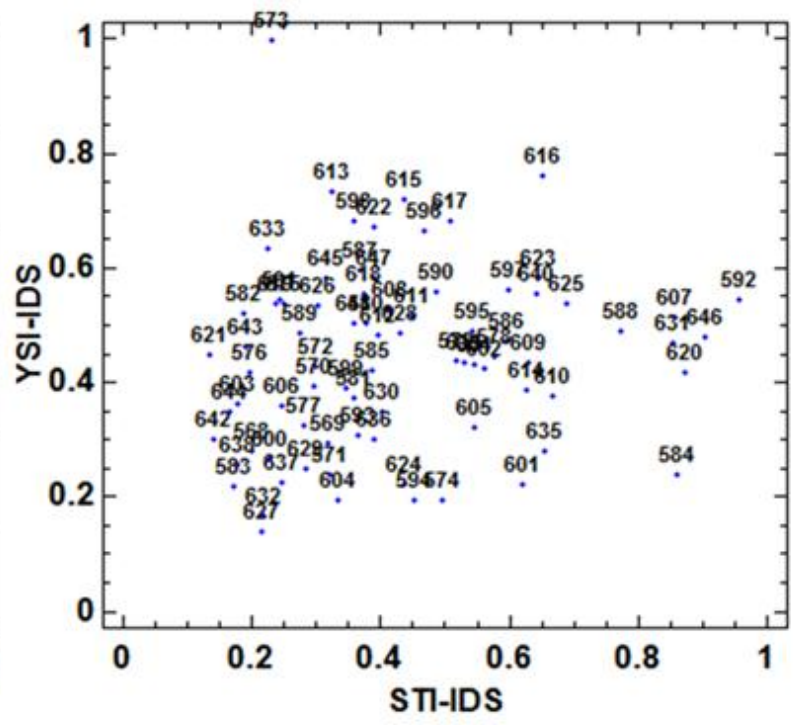

(ب)

شكل ه. باى يلات و شاخصهاى تحمل به كمآبى در ای لاين حاصل از تلاقى رقم ريحان به با جو وحشى HSPYI.

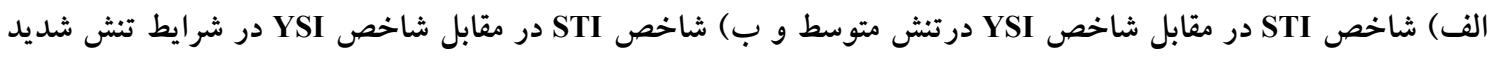

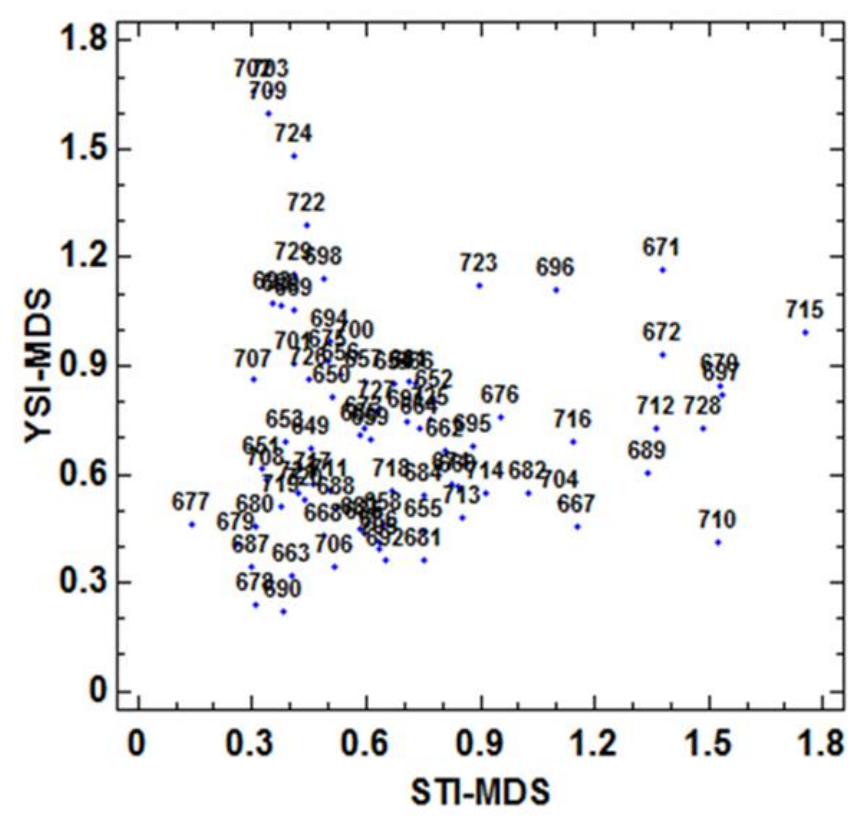

(الف)

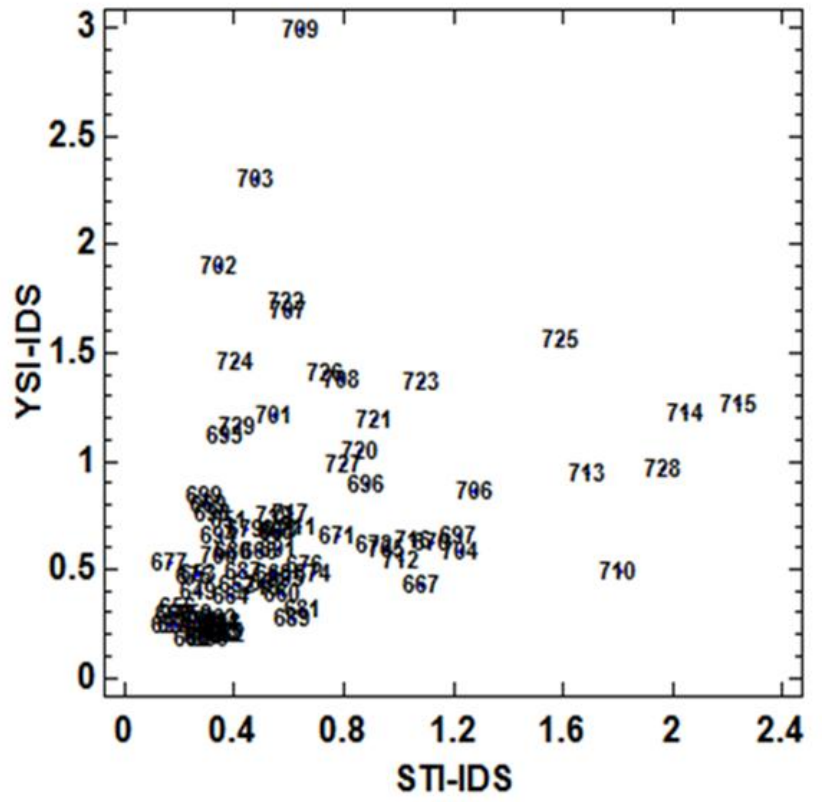

(ب)

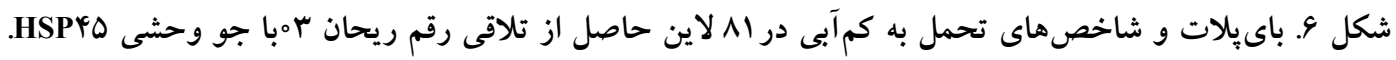

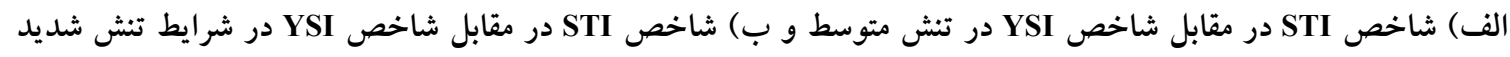


تفاوتهاى فيزيولوزيكى در گونه وحشى منجر به بـروز تحمـل

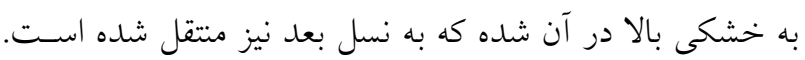

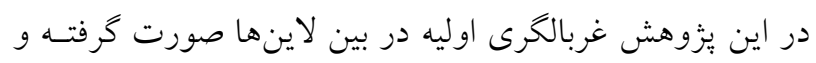

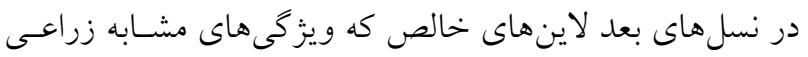

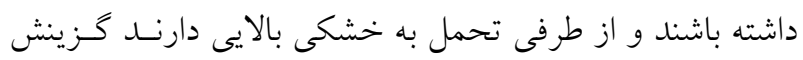
خواهند شد.

\section{نتيجه گيرى}

در اين مطالعه دو جمعيت در نسل F3 كه حاصـل نتساج تلاقى جو زراعى با دو نمونه جـو وحشى (HSPYI) HSPY ايجـاد

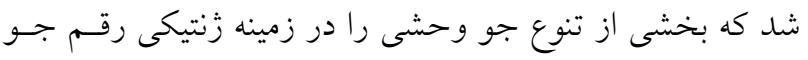

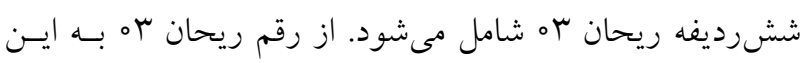

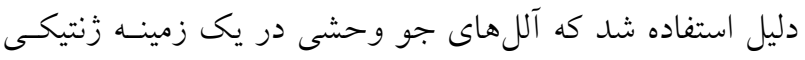

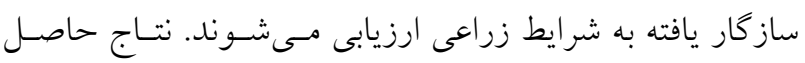

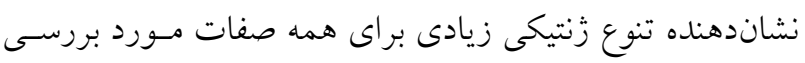

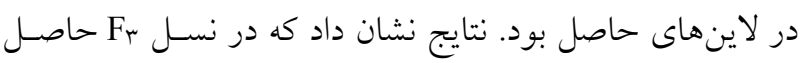

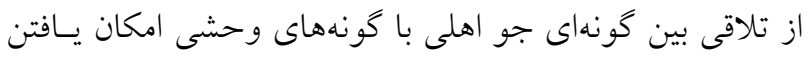

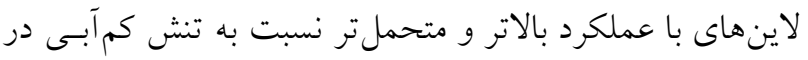

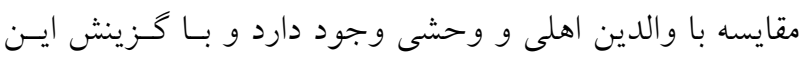

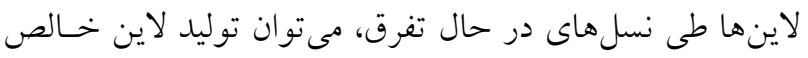

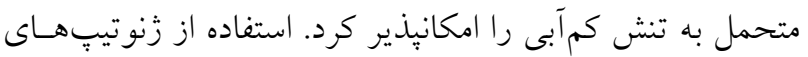
وحشى متفاوت در تلاقى با رقم زراعى جو مىتوانـــ منجـر بــــ

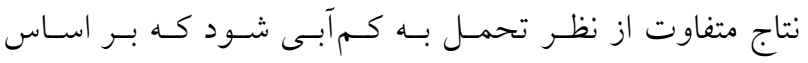

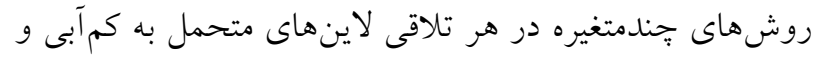
ير توليد براى ادامه يُزوهش شناسايى شدند.

شاخص مقدار بالايى داشته باشند، عملكـــد بـالايى در محسيط

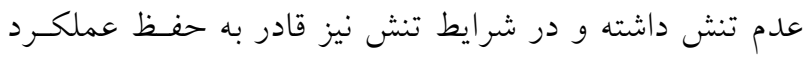

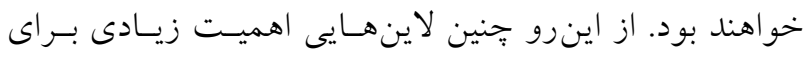

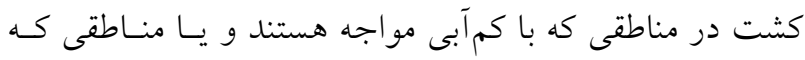

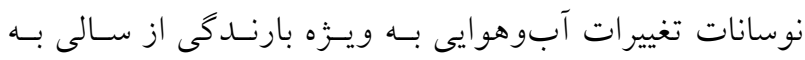

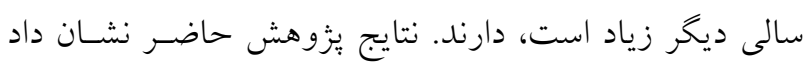
كه امكان ايجاد لاينهاى بسيار متحمل از جو از طريق تلاقى

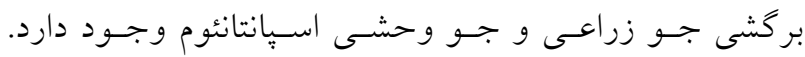
همجنين سطح تحمـل بـه خشكى در لايسنهـاى حاصـله بـه

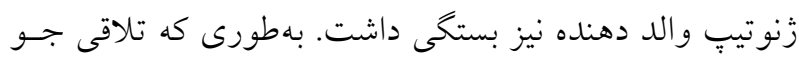

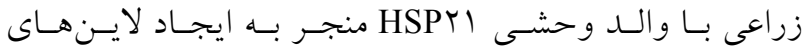

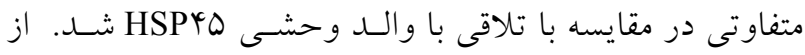

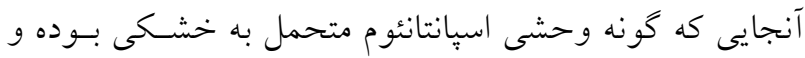

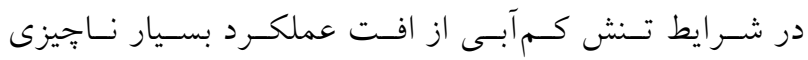

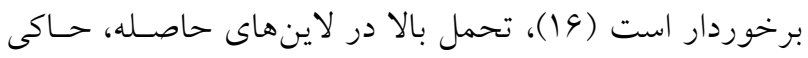

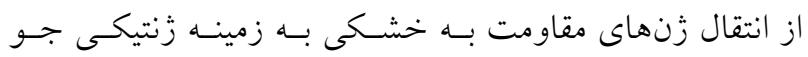

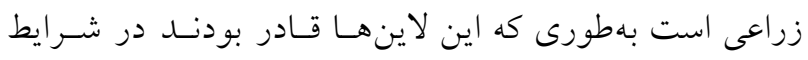

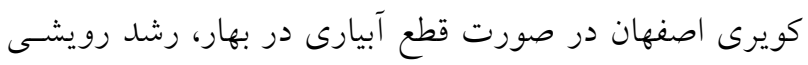

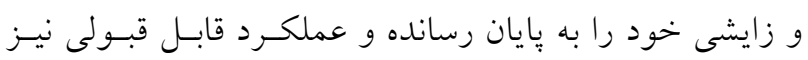

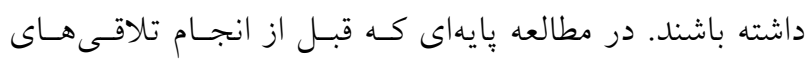

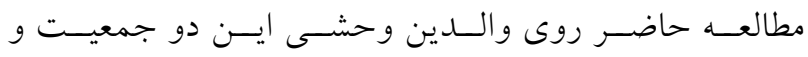

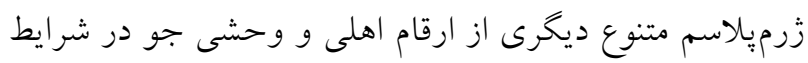

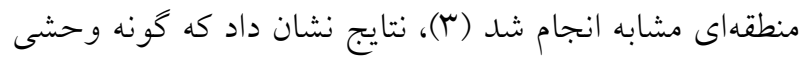

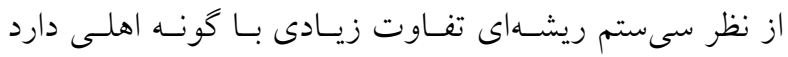

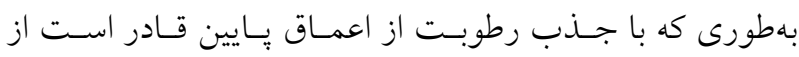
رطوبت ذخيره شده در خاك بهره ببرد. اين بديده بههمر اه ديخر

\section{منابع مورد استفاده}

1. Allen, R. G., L. S. Pereira, D. Raes and M. Smith. 1998. Crop evapotranspiration guidelines for computing crop water requirements. FAO Irrigation and Drainage 300: 1-15.

2. Baheri, S. F., A. Javanshir, H. Kazemi and S. Aharizad. 2005. The Effects of irrigation at different phenological stages on some traits in spring barley genotypes. Iranian, Journal of Agricultural and Crop Sciences 36(1): 169-176. (In Farsi).

3. Barati, M., M. M. Majidi, A. Mirlohi, F. Pirnajmodini and N. Sharif-Moghaddam. 2015. Response of cultivated and wild barley germplasm to drought stress at different developmental stages. Crop Science 55: 2668-2681.

4. Bouslama, M. and W. T. Schapaugh. 1984. Stress tolerance in soybean. Part 1: Evaluation of three screening 
techniques for heat and drought tolerance. Crop Science 24: 933-937.

5. Eberhart, S. A. and W. A. Russel. 1966. Stability parameters for comparing varieties. Crop Science 6: 36-40.

6. Eglinton, J. K., D. E. Evans., A. H. D. Brown, P. Langride, G. McDonald, S. P. Jefferies and A. R. Barr. 1998. The use of wild barley (Hordeum vulgare ssp. spontaneum) in breeding for quality and adaptation. In: Proceedings of the $10^{\text {th }}$ Australian Barley Technical Symposium. Sydney. pp. 565-569.

7. Fayyaz, N. 2008. Field evaluation of water stress tolerance in triticale. MSc. Thesis, Isfahan University of Technology, Iran.

8. Fernandez G. C. J. 1992. Effective selection criteria for assessing plant stress tolerance. In: Proceedings of the $1^{\text {th }}$ International Symposium on Adaptation of Food Crops to Temperature and Water Stress. AVRDC, Shanhua. pp. 257-270.

9. Hadjichristodoulou, A. 1993. The use of wild barley in crosses for grain production under dryland conditions. Euphytica 69: 211-218.

10. Ivandic, V., C. Hackett, Z. Zhang, J. Staub, E. Nevo, W. Thomas and B. Forster. 2000. Phenotypic responses of wild barley to experimentally imposed water stress. Journal of Experimental Botany 51: 2021-2029.

11. Johnson, R. A. and D. W. Wichern. 2007. Applied Multivariate Statistical Analisys, 4 ${ }^{\text {th }}$ ed., Prentic Hall International, INC. New Jersey.

12. Kutlu, I. and G. Kinaci. 2010. Evaluation of drought resistance indicates for yield and its components in three triticale cultivars. Journal of Tekirdag Agricultural Faculty 7: 95-103.

13. Lakew, B., J. Eglinton, R. J. Henry, M. Baum, S. Grando and S. Ceccarelli. 2011. The potential contribution of wild barley (Hordeum vulgare ssp. spontaneum) germplasm to drought tolerance of cultivated barley (H. vulgare ssp. vulgare), Field Crops Research 120: 161-168.

14. Morrel, P. L. 2011. Hordeum. pp. 309-320, In: C. Kole (Ed.), Wild Crop Relatives: Genomic and Breeding Resources, Cereals, Springer, New York.

15. Nevo, E. and G. Chen. 2011. Drought and salt tolerances in wild relatives for wheat and barley improvement. Plant Cell Environ 33: 670-685.

16. Saade, S., A. Maurer, M. Shahid, H. Oakey, S. M. Schmöckel, S. Negrão, K. Pillen and M. Tester. 2016. Yieldrelated salinity tolerance traits identified in a nested association mapping (NAM) population of wild barley. Scientific Reports 6: 32586. Doi: 10. 1038/srep 32586.

17. Shakhatreh, Y., N. Haddad, M. Alrababah, S. Grando and S. Ceccarelli. 2010. Phenotypic diversity in wild barley (Hordeum vulgare L. ssp. spontaneum (C. Koch) Thell.) accessions collected in Jordan, Genetic Resources. Crop Evolution 57: 131-146.

18. Shakhatreh, Y., O. Kafawin, S. Ceccarelli and H. Saoub. 2001. Selection of barley lines for drought tolerance in low rainfall areas. Journal of Agronomy and Crop Science 186: 119-127.

19. Sirousmehr, A., M. R. Shakiba, H. Alyari, M. Toorchi and A. Dabbagh Mohammadinasab. 2008. Effects of water deficit stress and plant density on yield and some morphological traits of Autumn-sown safflower cultivars. Pajouhesh and Sazandegi 78: 87-80. (In Farsi).

20. Srivastava, J. P., E. Acevedo and S. Varma. 1987. Drought Tolerance in Winter Cereals.. Cambridge University Press. Cambridge.

21. Van Oosterom, E. J., V. Mahalakshmi, F. R. Bidinger and K. P. Rao. 1996. Effect of water availability and temperature on the genotype-by-environment interaction of pearl millet in semi-arid tropical environments. Euphytica 89: 175-183.

22. Varshney, R. K., M. J. Paulo, S. Grando, F. A. Van Eeuwijk, L. C. P. Keizer, P. Guod, S. Ceccarelli, A. Kilian, M. Baum and A. Graner. 2012. Genome wide association analyses for drought tolerance related traits in barley (Hordeum vulgare L.), Field Crops Research 126: 171-180.

23. Zahravi, M. 2009. Evaluation of genotypes of wild barley (Hordeum spontaneum) based on drought tolerance indices. Seed and Plant Improvement Journal 1-25(3): 533-549. (In Farsi). 


\title{
Identification of Drought Tolerant Lines from Interspecific Hybridization in Two Different Genetic Backgrounds of Barley under Different Irrigation Regimes
}

\author{
M. Zeykani ${ }^{1}$, M. M. Majidi ${ }^{\star}$, M. Barati ${ }^{3}$, A. H. Osivand ${ }^{4}$ and D. Sarfaraz ${ }^{4}$
}

(Received: April 16-2019; Accepted: June 11-2019)

\begin{abstract}
Domestication and artificial selection have reduced the level of genetic variation in barley. Inter-specific hybridization is one of the most valuable ways to restore at least part of the lost variation. This study aimed to investigate genetic diversity and screening barley lines which possessed the desired traits, as well as drought tolerance, within two F3 populations derived by crossing a cultivated variety (Reihan 03) with two wild genotypes (HSP21 and HSP45). For this purpose, 162 F3 lines (including 81 lines from each breeding population) were evaluated in three different environments including no stress, moderate drought stress and severe drought stress. The results showed that in both populations, the greatest and smallest variation was obtained for the number of grains per spike and the number of days to physiological maturity, respectively. Mean of the plant height and 100-grain weight in the offspring obtained by crossing with HSP21 were lower than those of the population obtained by HSP45 under the moderate stress environment. Under severe stress environment, the offspring obtained by crossing Reihan 03 with the wild barley genotype HSP45 showed the increase of spike length, number of grains per spike, biological yield and grain yield, and the decrease of the 100-grain weight, as compared to the offspring obtained by crossing Reihan 03 with HSP21. The correlation coefficient analysis for the offspring resulting from crossing Reihan 03 with HSP21 in moderate and severe stress environments showed that grain yield was positively correlated with plant height, biological yield, stress tolerance index (STI) and yield stability index (YSI). The highest grain yield in (HSP21*Reihan 03) derived genotypes, in both control and moderate stress conditions, was revealed by the genotype 584, whereas the highest value in the severe stress condition belonged to the genotype 592 .The highest grain yield in (HSP45*Reihan 03) derived genotypes, in the three mentioned environments, was observed for the genotype numbers 689, 671 and 715, respectively. High-yielding lines in both no stress and drought stress conditions were identified by applying multivariate procedures and drought tolerance indices for further studies.
\end{abstract}

Keywords: Drought stress, Screening, Genetic variation, Hordeum spontaneum.

1, 2, 3, 4. Former MSc. Student, Professors, Former PhD. Student and Former BSc. Students, Respectively, Department of Agronomy and Plant Breeding, College of Agriculture, Isfahan University of Technology, Isfahan, Iran.

*: Corresponding Author, Email: majidi@iut.ac.ir 